\title{
PLEADING SECURITIES FRAUD
}

\author{
ELLIOTT J. WEISS*
}

I

\section{INTRODUCTION}

Seven years ago, Chief Judge Jon O. Newman highlighted the "inevitable tension" in securities class actions:

On the one hand, there is the interest in deterring fraud in the securities markets and remedying it when it occurs. That interest is served by recognizing that the victims of fraud often are unable to detail their allegations until they have had some opportunity to conduct discovery of those reasonably suspected of having perpetrated a fraud .... On the other hand, there is the interest in deterring the use of the litigation process as a device for extracting undeserved settlements as the price of avoiding the extensive discovery costs that frequently ensue once a complaint survives dismissal, even though no recovery would occur if the suit were litigated to completion. ${ }^{1}$

Judge Newman also recognized that notice pleading rules then in force favored the first of these interests. He held that complaints alleging securities fraud should not be dismissed-and plaintiffs thus should not be precluded from using the discovery process to search for evidence of fraud-"unless, in the familiar phrase from Conley v. Gibson, 'it appears beyond doubt that the plaintiff can prove no set of facts in support of his claim which would entitle him to relief.", 2

Two years later, Congress attempted to reverse the notice pleading system's pro-plaintiff bias by enacting the Private Securities Litigation Reform $\mathrm{Act}^{3}$ ("PSLRA" or "Reform Act") over President Clinton's veto. Congress took this step after finding that (1) securities class actions generally were initiated and controlled by plaintiffs' attorneys; (2) those attorneys routinely filed class actions alleging securities fraud "without regard to any underlying culpability of the issuer, and with only faint hope that the discovery process might lead eventually to some plausible cause of action"; and (3) plaintiffs' attorneys' "abuse of

Copyright (C) 2001 by Elliott J. Weiss

This article is also available at http://www.law.duke.edu/journals/64LCPWeiss.

* Charles E. Ares Professor of Law, James E. Rogers College of Law, University of Arizona

The author thanks Charles Ares and Tom Mauet for helpful conversations and comments; James Cox, Toni Massaro, and Adam Pritchard for comments on an earlier draft; and Eric Magnuson, Paul Moore, Saami Zain, Kris Harman, and Deborah Hansen for valuable research assistance.

This article was written in September 2000. Two of the principal cases discussed herein were pending as of that date. Developments in those cases through January 26, 2001 are discussed supra in notes 118 and 186 and in text accompanying notes 213 and 214 .

1. In re Time Warner, Inc. Sec. Litig., 9 F.3d 259, 263 (2d Cir. 1993).

2. Id. (citing Conley v. Gibson, 355 U.S. 41, 45-46 (1957)).

3. Private Securities Litigation Reform Act of 1995, Pub. L. No.104-67, 109 Stat. 737 (codified as amended in scattered sections of 15 U.S.C.) [hereinafter Reform Act or PSLRA]. 
the discovery process to impose [burdensome] costs" on defendants often led "the victimized part[ies] to settle" claims that had no merit. ${ }^{4}$ Congress observed that "investors always are the ultimate losers when extortionate 'settlements' are extracted from issuers," sanctions under Federal Rule of Civil Procedure 11, except in those cases involving truly outrageous misconduct," exacerbated the problems posed by abusive securities class actions. ${ }^{6}$

The Reform Act's legislative history contains no explicit discussion of either Conley v. Gibson or the notice pleading philosophy that has governed civil actions in federal courts since 1938 . The pleading and discovery requirements promulgated in the Reform Act cannot be reconciled with Conley v. Gibson; they clearly reflect congressional rejection of the philosophy of notice pleading in private securities fraud litigation. Section $21 \mathrm{D}(\mathrm{b})(1)$ requires every plaintiff alleging securities fraud to identify in her complaint each allegedly misleading statement, to "specify ... the reason or reasons why the statement [was] misleading," and, with respect to every allegation made on information and belief, to "state with particularity all facts on which that belief is formed." Section $21 \mathrm{D}(\mathrm{b})(2)$ requires every plaintiff, with respect to each statement or omission alleged to constitute a violation of section 10 (b) and Rule 10(b)-5, to "state with particularity facts giving rise to a strong inference that the defendant acted with [scienter]." Section $21 \mathrm{D}(\mathrm{b})(3)(\mathrm{A})$ directs courts to dismiss any complaint that does not meet the requirements of sections (b)(1) and (b)(2). ${ }^{10}$ Section $21 \mathrm{D}(\mathrm{b})(3)(\mathrm{B})$ effectively precludes a plaintiff from relying on the discovery process to uncover evidence of fraud by directing courts to stay all discovery "during the pendency of any motion to dismiss." Viewed as a whole, these provisions reflect an effort by Congress to reverse the litigation dynamic described by Judge Newman. ${ }^{12}$ They preclude a plaintiff from "conduct[ing] discovery of those [she] reasonably suspect[s] of having perpetrated a fraud"13 un-

4. H.R. REP. NO. 104-369, at 31 (1995), reprinted in 1995 U.S.C.C.A.N. 730, 730.

5. Id. at 32 .

6. Id. at 31 .

7. Securities Exchange Act of 1934, § 21D(b)(1), 15 U.S.C. $\S 78 u-4(b)(1)$ (Supp. IV 1998). This portion of section (b)(1) essentially duplicates Federal Rule of Civil Procedure 9(b)'s requirement that a plaintiff plead with particularity the circumstances constituting fraud.

8. Id. (emphasis added).

9. Id. $\S 21 \mathrm{D}(\mathrm{b})(2), 15$ U.S.C. $\S 78 \mathrm{u}-4(\mathrm{~b})(2)$ (emphasis added). The statute uses the term "the required state of mind," but, in the case of an action brought under section 10(b) and Rule 10b-5, the required state of mind is "scienter." See Ernst \& Ernst v. Hochfelder, 425 U.S. 185, 199 (1976).

10. See Securities Exchange Act of 1934, § 21D(b)(3)(A), 15 U.S.C. $\S 78 u-4(b)(3)(A)$ (Supp. IV 1998).

11. Id. $\S 21 \mathrm{D}(\mathrm{b})(3)(\mathrm{B}), 15$ U.S.C. $\S 78 \mathrm{u}-4(\mathrm{~b})(3)(\mathrm{B})$. The discovery stay provision provides for an exception if "the court finds upon the motion of any party that particularized discovery is necessary to preserve evidence or to prevent undue prejudice to that party." Id. Apart from this exception, discussed infra at text accompanying notes 233-237, courts uniformly have interpreted section $21 \mathrm{D}(\mathrm{b})(3)(\mathrm{B})$ to preclude a plaintiff from conducting discovery prior to the time a motion to dismiss is filed. See id.

12. See supra text accompanying note 1 .

13. In re Time Warner, Inc. Sec. Litig., 9 F.3d 259, 263 (2d Cir. 1993). 
less she first is able to file a complaint, without the benefits of discovery, that satisfies the stringent pleading requirements set forth in sections (b)(1) and (b)(2).

Most commentary to date has focused on two questions relating to those requirements: (1) Are facts that suggest a defendant acted recklessly sufficient to create a strong inference of scienter? (2) Are facts that suggest a defendant had a motive and the opportunity to engage in securities fraud, standing alone, sufficient to create a strong inference of scienter? ${ }^{14}$

This article focuses on other issues, dealing primarily with what I call the "Basis Requirement"-the statement in section (b)(1) that with respect to every allegation made on information and belief, a plaintiff must "state with particularity all facts on which that belief is formed." In addition, this article addresses how the Basis Requirement relates to the "Strong Inference Requirement" set forth in section (b)(2) and what it means to create a strong inference of scienter. ${ }^{15}$

Issues associated with the Basis Requirement and its relationship to the Strong Inference Requirement are far more significant than the issues concerning degrees of recklessness and motive and opportunity that have preoccupied commentators to date. ${ }^{16}$ The Ninth Circuit's decision in In re Silicon Graphics, Inc. Securities Litigation ${ }^{17}$ illustrates this point. The panel there divided, 2-1, on two questions. The first concerned how to define when recklessness constitutes scienter. The majority held that a plaintiff must plead facts sufficient to give rise to a strong inference that a defendant acted with "deliberate

14. See, e.g., Robert J. Giuffra, Jr., Pleading Scienter Under the PSLRA, N.Y. L.J., July 22, 1999, at 5 (Mr. Giuffra is identified as "a principal drafter of the PSLRA"); Marilyn F. Johnson et al., In re Silicon Graphics Inc.: Shareholder Wealth Effects Resulting from the Interpretation of the Private Securities Litigation Reform Act's Pleading Standard, 73 S. CAL. L. REV. 773 (2000); Matthew Roskoski, Note, A Case-By-Case Approach to Pleading Scienter Under the Private Securities Litigation Reform Act of 1995, 97 MICH. L. REV. 2265 (1999). The principal prior exception to this trend is Miranda S. Schiller \& Haron W. Murage, Information and Belief Pleading Under the Reform Act, 8 SEC. REFORM ACT LITIG. REP. 8 (Oct. 1999); see also Symposium: Securities Fraud Litigation After Silicon Graphics, 7 SEC. REFORM ACT LiTIG. REP. 798, 807-11 (Aug.-Sept. 1999) (discussing the Basis Requirement, including remark of Bruce G. Vanyo, Esq., counsel for defendants in Silicon Graphics, to the effect that the court's ruling on that requirement "is the more significant part" of its decision).

15. See supra text accompanying note 8 .

16. I exclude from this list the question of whether the PSLRA should be interpreted to preclude liability based on recklessness in all suits brought under section $10(\mathrm{~b})$ and Rule 10b-5. As a number of courts have held, the language of the PSLRA clearly is directed at establishing a pleading standard, not changing the substantive definition of "scienter." Thus, the question of whether recklessness can constitute scienter remains unresolved at the Supreme Court level. See Ernst \& Ernst v. Hochfelder, 425 U.S. 185, 193 n.12 (1976). However, it has always seemed clear to me that the PSLRA could not reasonably be interpreted to abolish liability for reckless conduct. See Elliott J. Weiss \& Janet E. Moser, Enter Yossarian: How to Resolve the Procedural Catch-22 that the Private Securities Litigation Reform Act Creates, 76 WASH. U. L.Q. 457, 466 n.47 (1998). In fact, Congress's adoption of an actual intent standard in certain circumstances, see, e.g., § 21E of the Securities Exchange Act of 1934, 15 U.S.C. $\S$ 78 u-5 (Supp. IV 1998), can be read as an implicit congressional endorsement of the uniform holdings of the courts of appeals that a high degree of recklessness qualifies as scienter. See Greebel v. FTP Software, Inc., 194 F.3d 185, 200-01 (1st Cir. 1999).

17. 183 F.3d 970 (9th Cir. 1999). 
recklessness," ${ }^{18}$ while Judge Browning argued in dissent that facts sufficient to support a strong inference of simple recklessness should suffice. ${ }^{19}$

The dispositive question, however, concerned the proper interpretation of the Basis Requirement. Central to the plaintiffs' claim were allegations that certain internal reports, including an alleged "Stop Ship" report, had placed the senior management of Silicon Graphics, Inc. ("SGI") on notice of problems that SGI was experiencing with the Toshiba ASIC chip-a primary component of the "Indigo2 Impact Workstation" that SGI had claimed it was about to bring to market. The court held that in the absence of specifics such as the dates of the alleged reports and the names of the authors and addressees, it would not credit those allegations because it could not determine whether plaintiffs' claim that SGI knew its statements about the Indigo2 were false reflected anything more than their speculative belief that a fraud must have occurred. $^{20}$ Judge Browning disagreed, arguing that "precise details" of the kind demanded by the majority were "neither expected nor required at the pleading stage of the proceedings." ${ }^{21}$ Moreover, Judge Browning pointed out, if the court treated as true plaintiffs' allegations concerning the Stop Ship and other internal reports, ${ }^{22}$ those allegations clearly were sufficient to "form the basis for a strong inference that SGI's officers knew the representations they were making to the public were false when made." ${ }^{23}$

Note the import of the last quoted statement. It was the majority's conclusion that the plaintiffs had not satisfied the Basis Requirement that determined the outcome in Silicon Graphics, not its conclusion regarding "deliberate recklessness." Put differently, had the majority agreed with Judge Browning that plaintiffs' allegations concerning the Stop Ship report should be treated as true for the purpose of deciding defendants' motion to dismiss, the majority would have had no choice but to agree with Judge Browning that plaintiffs had pled facts sufficient to support a strong inference that SGI had made public statements with actual knowledge that those statements were false. That, in turn, would have rendered irrelevant the debate between the majority and Judge Browning over whether simple recklessness or "deliberate recklessness" is the equivalent of scienter. ${ }^{24}$

18. See id. at $974-79$.

19. See id. at 991-96 (Browning, J., dissenting).

20. See id. at $984-85$.

21. Id. at 999 (Browning, J., dissenting).

22. As would be the case under Conley v. Gibson, 355 U.S. 41 (1957).

23. Silicon Graphics, 183 F.3d at 999-1001 (Browning, J., dissenting) (emphasis added).

24. In fact, given the majority's holding that plaintiff had not met the Basis Requirement, its holding concerning "deliberate recklessness" could be considered dicta.

It is useful, in this regard, to consider the finding of Professors Johnson, Nelson, and Pritchard that there was a statistically significant, positive stock market reaction to SGI. See Johnson et al., supra note 14. The authors attribute the reaction to the court's holding that the Reform Act requires evidence of deliberate recklessness. It seems equally plausible that the market was reacting to the court's insistence that plaintiffs plead the basis for claims made on information and belief. 
The Silicon Graphics court's interpretation of the Basis Requirement, in my view, is correct and, more important, is critical to implementing Congress's purpose in enacting the pleading and discovery stay provisions of the Reform Act. Part II of this article explains further why I believe this to be so. Part III comments briefly on the holding in Silicon Graphics concerning "deliberate recklessness" and argues that it does not differ significantly from the scienter standards most other Courts of Appeals have adopted. Part IV describes and analyzes the portions of the First Circuit's decision in Greebel v. FTP Software, Inc. ${ }^{25}$ that interpret the Basis Requirement and analyze its relationship to the Strong Inference Requirement. ${ }^{26}$ Part V discusses cases pending in the Second and Third Circuits that raise important interpretative issues relating to sections (b)(1) and (b)(2). How those courts resolve those issues will provide important clues as to whether the lower federal courts will follow a unified or a fragmented approach to interpreting the Reform Act's pleading requirements. Part VI, the conclusion, highlights the policy consequences of the approach to interpreting sections (b)(1) and (b)(2) that this article argues courts should adopt and outlines alternative strategies courts could pursue.

\section{II}

\section{WHY THE BASIS REQUIREMENT IS CRITICAL}

To appreciate the critical importance of the Basis Requirement, one first must understand the fundamental pleading problem faced by an investor who suspects or believes she is the victim of a disclosure fraud. ${ }^{27}$ An issuer will have disclosed some unexpected bad news, such as a decline in sales and earnings, a problem in bringing a product to market, or a discovery of fraudulent practices at a division or subsidiary. The issuer's announcement will have precipitated a sharp decline in the price of its stock. ${ }^{28}$ In virtually every such situation, the issuer also will have issued "earlier, cheerier" ${ }^{29}$ statements relating to the subject discussed in the "bad news" release. Without conducting a costly investigation or obtaining access to the issuer's files and personnel, however, the investor and her attorney will find it difficult to ascertain whether the issuer just became aware of the bad news or whether it knew or suspected the bad news at the time the issuer made the "earlier, cheerier" statements.

25. 194 F.3d 185 (1st Cir. 1999).

26. In an earlier article, I suggested that the First Circuit's pre-Reform Act jurisprudence concerning pleading securities fraud could serve as a model for other circuits when applying the Reform Act's new pleading requirements. See Elliott J. Weiss, The New Securities Fraud Pleading Requirement: Speed Bump or Road Block?, 38 ARIZ. L. REV. 675, 695-99 (1996).

27. I have previously discussed this issue. See Weiss, supra note 26; Weiss \& Moser, supra note 16. Ongoing study has enhanced my understanding of the pleading issues involved in securities fraud litigation and has led me to modify (or, more charitably, to improve and refine) my thinking about these issues.

28. Although a few such cases involve claims relating to positive corporate developments, see, e.g., Basic, Inc. v. Levinson, 485 U.S. 224 (1988), the vast majority involve claims that corporations have misrepresented or failed to disclose bad news.

29. In re Glenfed, Inc. Sec. Litig., 42 F.3d 1541, 1548 (9th Cir. 1994) (en banc). 
The investor's attorney, if she is experienced, will be acutely aware that a complaint alleging simply that the issuer "must have known" the bad news at the time it made the "earlier, cheerier" statements will be dismissed on the ground that it impermissibly pleads no more than "fraud by hindsight." ${ }^{30}$ But if the investor's attorney is skilled as well as experienced, she can draw with relative ease on the information in the bad news release and other publicly available information to draft a complaint alleging that, at the time the issuer made the "earlier, cheerier" statements, either the issuer and its senior managers had learned from internal reports the negative information later disclosed in the "bad news" release or that "red flags" had placed the issuer and its senior managers on notice that those negative developments were highly likely to occur. Finally, the investor's attorney will know that if the court can be persuaded to treat those allegations as true, they also will support a strong inference that the issuer and its senior managers made the "earlier, cheerier" statements either with actual knowledge that they were false or in reckless disregard of that possibility. ${ }^{31}$

The complaint in Silicon Graphics ${ }^{32}$ illustrates this genre of creative drafting. ${ }^{33}$ In July 1995, SGI announced plans to produce the Indigo2, a new line of graphic design computers that would compete with a line of Hewlett Packard workstations. SGI said that it expected to ship the Indigo2 in volume by September 30, 1995, and to ship an upgraded version of the Indigo 2 by January 1,

30. The courts have uniformly rejected complaints that allege no more than "fraud by hindsight." See, e.g., Glenfed, 42 F.3d at 1549; Greenstone v. Cambex Corp., 975 F.2d 22, 25-26 (1st Cir. 1992); DiLeo v. Ernst \& Young, 901 F.2d 624, 627 (7th Cir. 1990); Denny v. Barber, 576 F.2d 465, 469-70 (2d Cir. 1978).

31. In my experience, persons unfamiliar with securities fraud litigation often find it difficult to appreciate the relative ease with which a skilled and experienced plaintiffs' attorney can draft such a seemingly particularized complaint. Consequently, in the Appendix, I set forth three illustrative examples, two based in pre-PSLRA Ninth Circuit decisions holding that such complaints should not be dismissed and one based on a post-PSLRA decision dismissing such a complaint.

An article in Fortune illustrates how the most prominent plaintiffs' firm specializing in prosecuting securities class actions has used such complaints to secure lucrative settlements:

Bill Lerach is explaining what he needs to file one of his infamous shareholder class-action lawsuits: "Stock drops. Insiders trading. A revelation of bad news. You're not going to have that and come up dry. It's not going to happen."... His rationale is that his long experience has given him an unerring instinct for corporate wrongdoing. "It's almost like having X-ray vision," he boasts. "I'm almost always right. I'm seldom wrong." Then, once Lerach is allowed to begin discovery-and search for damning internal documents-well, at that point, the game is pretty much over. "You can always find a document to incriminate them," he says.

Peter Elkind, The King of Pain is Hurting, ForTune, Sept. 4, 2000, at 190.

My awareness of these and similar practices has made me unsympathetic to arguments in favor of allowing plaintiffs to prosecute "long shot" securities claims. See Charles M. Yablon, A Dangerous Supplement? Longshot Claims and Private Securities Litigation, 94 Nw. U. L. REV. 567 (2000).

32. The discussion that follows relates to the First Amended Consolidated Complaint, In re Silicon Graphics, Inc. Sec. Litig., No. C96-0393FMS, 1996 U.S. Dist. LEXIS 16989 (N.D. Cal. Sept. 25, 1996) [hereinafter SGI FAC] (visited Feb. 27, 2001) <http://securities.stanford.edu/com plaints/sgi/96cv00393/068.html>.

33. The complaint was drafted by the San Diego office of Milberg Weiss Bershad Hynes \& Lerach, LLP, which ranks among the most skilled and experienced offices of plaintiffs' attorneys in the United States. 
1996. SGI also claimed that the Indigo2 would help the company sustain a forty percent growth rate. ${ }^{34}$ Within a few weeks of that announcement, SGI stock reached an all-time high. ${ }^{35}$

Throughout the remainder of 1995 , SGI continued to issue positive statements regarding the Indigo 2 and denied negative rumors about its performance. $^{36}$ Then, on January 2, 1996, SGI unexpectedly announced "disappointing second quarter results and acknowledged that revenue growth for the year would be much lower than expected." ${ }^{37}$ SGI senior management admitted to securities analysts on January 17, 1996 "that SGI had been unable to fill Indigo2 orders because of a shortage of [Toshiba] ASIC chips and other primary components." ${ }^{38}$ As might be expected, SGI's stock price declined following these announcements.

Plaintiffs' attorneys, in addition to learning of these problems in January 1996, either learned from current or former SGI employees or simply assumed that SGI, like most major corporations, had an elaborate management information system that generated reports about major operational problems as soon as they occurred. Drawing on that information (or that combination of information and assumptions), they drafted a complaint alleging securities fraud. The key assertion was that SGI's senior management knew, not later than midSeptember 1995, that SGI was experiencing problems with the Toshiba ASIC chip, a primary component of the Indigo2, which made it impossible for SGI to implement the Indigo2 program on the schedule it had announced. Plaintiffs alleged that as a consequence, all the positive statements SGI and its senior managers made about the Indigo2 program from mid-September until the end of November 1995 were false and were made with actual knowledge that they were false.

More specifically, the key portions of plaintiffs' First Amended Consolidated Complaint assert:

34. [S]GI's management information system was capable of generating reports on a daily basis showing orders received (by product), shipments (by product), inventories (by product), as well as overall corporate revenue, cash balances, inventories, etc. As a result of this system, SGI's top managers, such as [CEO Edward R.] McCracken, [Sr. V.P. Forest] Baskett, [Sr. V.P. Robert K.] Burgess, [Sr. V.P. Michael] Ramsey, [Sr. V.P. William M.] Kelly and [Sr. V.P. Teruyasu] Sekimoto, were aware of the corporation's performance on a daily basis and were thus aware, virtually immediately, of any significant problems with orders, product production, shipment delays or inventories, etc.

37. When SGI encountered serious quality and performance problems with the Indigo2 IMPACT ${ }^{\mathrm{TM}}$ Workstations due to the ASIC chip performance problems as it attempted to assemble and ship the Indigo $2 \mathrm{IMPACT}^{\mathrm{TM}}$ Workstations in volume in

34. See In re Silicon Graphics, Inc. Sec. Litig., 183 F.3d 970, 980 (9th Cir. 1999).

35. See id.

36. See id. at 981-82.

37. Id. at 982 .

38. Id. 
Sept. 1995, SGI's internal corporate procedures required that the managers of the Indigo2 IMPACT ${ }^{\mathrm{TM}}$ project immediately advise top management of this problem in midSept. 1995 via a "Stop Ship" report. Such a report was issued and contained the following: (1) identified the problem; (2) notified top management of the impact on volume shipments and revenue; and (3) requested input on satisfying customer demands in light of the available volume. Subsequently, within three weeks the marketing, engineering and manufacturing managers prepared a report with the Indigo $2 \mathrm{IMPACT}^{\mathrm{TM}}$ Program Director detailing the nature of the problem, its cause, revenue impact, how the problem would be solved, how long the solution would take, and what impact the problem and the solution would have on that project's ability to meet its previously forecasted or budgeted sales.

38. Thus, when the serious deficiencies with the ASIC chips being used in the Indigo2 IMPACT ${ }^{\mathrm{TM}}$ Workstations were discovered in mid-Sept. 1995, McCracken, Baskett, Burgess, Kelly, Ramsey and Sekimoto were immediately advised of the problems by the Indigo2 IMPACT ${ }^{\mathrm{TM}}$ project managers .... After they were advised of this problem in late Sept. 1995 by the Indigo 2 IMPACT $^{\mathrm{TM}}$ project team, there immediately occurred a series of meetings among these top managers, including the Individual Defendants, to evaluate the seriousness of the problem, what could be done to attempt to fix it, as well as which customer orders would be filled and to what extent. At this time, in what was known inside SGI as the "conspiracy of silence," the top officers of SGI, including the Individual Defendants, agreed that in order to conceal the problem from the marketplace-disclosure of which would result in severely negative impact on sales of the Indigo 2 IMPACT $^{\mathrm{TM}}$ products, a further loss of SGI's competitive position to Hewlett Packard and the collapse of SGI's stock-that the problems with the ASIC chips would be kept secret and that SGI would falsely tell it [sic] customers, the marketplace and securities analysts that it had achieved "volume" shipments of the Indigo 2 IMPACT ${ }^{\mathrm{TM}}$ Workstations, that it was not encountering any production or component part problems with the product and that the reason customers were not receiving the full amounts of Indigo $2 \mathrm{IMPACT}^{\mathrm{TM}}$ Workstations ordered was the extraordinary demand for the product which SGI simply could not meet.

39. Internally at SGI, the problems with Indigo $2 \mathrm{IMPACT}^{\mathrm{TM}}$ Workstation production due to ASIC chip yield problems from Toshiba continued to be encountered throughout Oct. 1995, and were so serious that shipments of the Indigo2 IMPACT ${ }^{\mathrm{TM}}$ Workstations remained well below the levels previously forecast .... This information was provided to each of the defendants in the Oct. 1995 "Flash" financial report ... distributed to them no later than Nov. 3 or $6 \ldots$

40. Internally at SGI, the problems with Indigo2 IMPACT ${ }^{\mathrm{TM}}$ Workstation production due to ASIC chip yield problems continued to be encountered throughout Nov. 1995. The problems with ramping up of manufacturing of the R10000 ASIC chip also continued and SGI knew that there was no possibility of shipping its upgraded, high-end Indigo2 IMPACT Workstations in the volume necessary to achieve announced goals in the third quarter of FY96 ... This information was provided to each of the defendants in the Nov. 1995 "Flash" financial report... distributed to them no later than Dec. 4 or $5 \ldots$. .

41. Because of the foregoing, each of the Individual Defendants was aware of SGI's FY96 forecast and budget and of the internal reports detailing the ASIC chip problems (Stop Ship and Recovery Report), and the financial reports comparing SGI's actual results to those budgeted and/or forecasted. Based on the negative internal reports specified earlier about the Indigo 2 IMPACT ${ }^{\mathrm{TM}}$ Workstation and reports of the Company's actual performance compared to that budgeted and forecasted, the Individual Defendants each knew SGI's business was not performing as well as publicly represented, that SGI was plagued by an inability to ship necessary volume due to an inadequate supply of suitable ASIC chips from Toshiba, that problems with ramping up manufacturing with the R10000 would impact future volume, that serious and persistent problems with SGI's North American direct sales force were resulting 
in reduced productivity, i.e., revenue shortfalls, weak OEM sales and weak sales in Germany and France, and thus, SGI could not possibly achieve near to $40 \%$ growth in the second quarter of FY96 or FY96 as a whole. Thus, defendants each actually knew that the forward-looking public statements issued during the Class Period about SGI were false and misleading when made and actually knew or recklessly disregarded that the non-forward-looking statements issued during the Class Period about SGI were false and misleading when made. ${ }^{39}$

Plaintiffs said they based these allegations "upon the investigation of their counsel, which included a review of SGI's SEC filings, securities analysts reports and advisories about the Company, press releases issued by the Company, media reports about the Company and discussions with consultants ...." Plaintiffs added that they believed "that substantial evidentiary support will exist for the[se] allegations . . . after a reasonable opportunity for discovery."

The Silicon Graphics complaint undoubtedly was drafted with great care. At first glance, it appears to set forth a detailed claim that SGI knew in September 1995 about problems with the Indigo2 program and the ASIC chip but did not disclose those problems until January 1996. Close analysis, however, makes clear that plaintiffs' allegations represent no more than a skillfully disguised claim of "fraud by hindsight" - a claim that, in September 1995, SGI must have been aware of the problems it disclosed in January 1996.

For example, the first clause of the first sentence of paragraph 37 makes what appears to be an unqualified statement of historic fact-that "SGI encountered serious quality and performance problems with the Indigo $2 \ldots$ due to the ASIC chip performance problems ... in Sept. 1995." Nowhere in paragraph 37, however, (or anywhere else in the complaint) do plaintiffs provide any corroborating details - apart from the information SGI disclosed in January 1996-to support this conclusory assertion. Plaintiffs might contend that the second and third sentences of paragraph 37, which describe an alleged Stop Ship report and an alleged report to the Indigo 2 project manager, should be construed as providing adequate corroboration for the assertion made in the first sentence. But while those sentences purport to describe the content of the alleged reports, they do so in general terms and neither quote from the alleged reports nor provide any indication of plaintiffs' basis for their claim that such reports were issued. Rather, plaintiffs simply pile additional assertions-that the reports describing the problems with the ASIC chip were issued-on top of their initial assertion that SGI was aware of those problems in September 1995.

In paragraph 38 , plaintiffs make additional allegations that build on these assertions: (1) McCracken and the other individual defendants were immediately advised of the alleged problems with the ASIC chip; (2) those defendants held a series of meetings to discuss those problems and entered into a "conspiracy of silence" to conceal those problems from the marketplace; and (3) those defendants agreed to falsely represent to customers and analysts that SGI had

39. SGI FAC, supra note 32, II II 34, 37-41 (emphasis added).

40. Id. II 96.

41. Id. 
achieved volume production of the Indigo2. Based on the information plaintiffs included in their complaint, it is impossible to determine whether plaintiffs had any factual basis for these claims or whether they simply were speculating that, given SGI's disclosure in January 1996 that it had experienced problems with the Indigo2 program and the ASIC chip, this probably is what occurred.

Paragraphs 39 and 40 are more of the same. As for paragraph 41, plaintiffs simply set forth the conclusions that would follow logically from the four paragraphs that precede it if but only if one accepts as true the allegations in paragraphs 37-40. That is, if SGI began to experience problems with the ASIC chip in September 1995, if the Stop Ship and program manager's reports were issued and brought those problems to the attention of SGI's senior managers, if those managers thereafter conspired to keep the problems with the ASIC chip secret and to misrepresent the Indigo2 program to SGI's customers and to securities analysts, and if those managers continued to misrepresent material information about the ASIC chip and the Indigo2 program during October and November 1995, then it would follow that SGI and the individual defendants had actual knowledge that both the forward-looking and the non-forward-looking statements that SGI and the individual defendants made about the Indigo 2 program between mid-September and the end of November 1995 were false at the time they were made. ${ }^{42}$

As noted above, Judge Browning took the position that plaintiffs alleged the "facts" set forth in paragraphs 37-41 with sufficient particularity to meet the requirements of sections (b)(1) and (b)(2). ${ }^{43}$ Had the majority agreed with him, the court would have left open the door ${ }^{4}$ to claims of "fraud by hindsight" masquerading as claims of disclosure fraud. ${ }^{45}$ The complaint in Silicon Graphics would then have provided plaintiffs' attorneys with a template for the conversion of hindsight suspicions of fraud into what, at least in the Ninth Circuit, would be an adequately particularized claim of securities fraud. ${ }^{46}$

42. But if SGI did not become aware of the nature and magnitude of the problems with the ASIC chip until shortly before its January 1996 announcements, this entire house of cards collapses.

43. See In re Silicon Graphics, Inc. Sec. Litig., 183 F.3d 970, 997-1001 (9th Cir. 1999) (Browning, J., dissenting); supra text accompanying notes 21-23.

44. I say "left open the door" because two pre-Reform Act Ninth Circuit decisions, Fecht v. Price Co., 70 F.3d 1078 (9th Cir. 1995), and Cooper v. Pickett, 122 F.3d 1186 (9th Cir. 1997), held that complaints based on unsupported allegations similar to those made by plaintiffs in Silicon Graphics satisfied the particularity requirement of Federal Rules of Civil Procedure 9(b). Ihave previously argued that those cases were wrongly decided. See Weiss \& Moser, supra note 16, at 469 \& n.63. Yourish v. California Amplifier, 191 F.3d 983, 992-98 (9th Cir. 1999), a post-Reform Act case that was decided after (but does not cite) Silicon Graphics appears to reverse Fecht and Cooper's interpretation of Rule 9(b) without explicitly stating that it is doing so.

45. These were just the kind of speculative claims Congress sought to discourage when it passed the Reform Act. See supra text accompanying notes 4-5.

46. The approach to pleading fraud followed by plaintiffs' attorneys in Silicon Graphics is also economically attractive in that it allows those attorneys to draft complaints on the basis of readily available information. See generally John C. Coffee, Jr., Understanding the Plaintiff's Attorney: The Implications of Economic Theory for Private Enforcement of Law Through Class and Derivative Actions, 86 COLUM. L. REV. 669 (1986). In this regard, it is notable that the Silicon Graphics plaintiffs' description of the basis for their allegations includes no mention of interviews with current or former 
A majority of the court, however, rejected Judge Browning's argument and held that the complaint "neither states facts with sufficient particularity nor raises a strong inference of deliberate recklessness." ${ }^{47}$ More specifically, the court refused to credit plaintiffs' allegations concerning the alleged internal reports and the alleged "conspiracy of silence" because the "complaint does not include adequate corroborating details." ${ }^{48}$ The court continued:

[Plaintiff] does not mention, for instance, the sources of her information with respect to the reports, how she learned of the reports, who drafted them, or which officers received them. Nor does she include an adequate description of their contents which we believe-if they did exist-would include countless specifics regarding ASIC chip shortages, volume shortages, negative financial projections, and so on. We would expect that a proper complaint which purports to rely on the existence of internal reports would contain at least some specifics from those reports as well as such facts as may indicate their reliability. ${ }^{49}$

Then the court made the following critical observation:

In the absence of such specifics, we cannot ascertain whether there is any basis for the allegations that the officers had actual or constructive knowledge of SGI's problems that would cause their optimistic representations to the contrary to be consciously misleading. In other words, in the absence of such specifics, we cannot determine whether there is any basis for alleging that the officers knew that their statements were false at the time they were made-a required element in pleading fraud. [Plaintiff] would have us speculate as to the basis for the allegations about the reports, the severity of the problems, and the knowledge of the officers. We decline to do so.

[Plaintiff] is required to state facts giving rise to a strong inference of deliberate recklessness or intent. It is not enough for her to state facts giving rise to a mere speculative inference of deliberate recklessness, or even a reasonable inference of deliberate recklessness.

The court's reasoning is sound. Allegations of securities fraud must be based on testimonial or documentary sources. Where the source is a document that the plaintiff possesses or has seen, one would, as the court in Silicon Graphics suggests, expect the plaintiff to quote the relevant portions of that document in the complaint. ${ }^{51}$ If the plaintiff purports to do so, the court should treat those allegations as adequately corroborated for two reasons: First, section (b)(1) requires a plaintiff to plead only "facts," not evidence; and second, the plaintiff and her attorney probably would violate Rule 11(b) of the Federal Rules of Civil Proceure and would run the risk of incurring substantial sanctions

SGI employees or other similar investigatory activity. See supra text accompanying notes 39-41 (discussing SGI FAC).

47. Silicon Graphics, 183 F.3d at 984.

48. Id. at 985. Although the complaint before the court was filed on behalf of several named plaintiffs, see SGI FAC, supra note 32, If 25, the court discussed it as if it had been filed only by Deanna Brody, who filed the first complaint against SGI. See Silicon Graphics, 183 F.3d at 979-91.

49. Silicon Graphics, 183 F.3d at 985.

50. Id. (citation omitted). The court relied on an amalgam of sections (b)(1) and (b)(2). The last quoted statement suggests that the complaint should be dismissed because it fails to give rise to a strong inference of scienter, but the reason the complaint fails to do so lies in plaintiffs' failure to meet the Basis Requirement.

51. See, e.g., Ruskin v. TIG Holdings, Inc., No. CIV. 1068(LLS), 2000 WL 1154278, at *2-3 (S.D.N.Y. Aug. 14, 2000) (citing plaintiffs' quotation of memoranda prepared by officers of defendant corporation). 
were they, without qualification, to purport to quote in a securities fraud complaint a document that they did not possess and had never seen. ${ }^{52}$

Consider, next, a complaint that does not include direct quotations from a purported document. In the absence of such quotations, a court reasonably can assume that the plaintiff does not possess and has not seen the alleged document. That, of course, does not mean the document does not exist. The plaintiff may have learned of the document and its contents from a person who represented that she had seen the document or had learned of its contents from another. $^{53}$ If that is the case, Silicon Graphics holds that the plaintiff must set forth specifics sufficient to allow the court to assess the credibility of her allegations. $^{54}$

The same is true with respect to allegations concerning oral statements purportedly made to or by named individuals. If the court is to assess whether the plaintiff has a reasonable basis for each such allegation, and whether that allegation, in combination with the plaintiff's other allegations, gives rise to a strong inference that a defendant acted with scienter, the plaintiff must tell the court how she learned of those oral statements, from whom, and how her sources learned of those statements (for example, whether the source heard the alleged statement personally or was told by some third person that the statement was made).

In short, Silicon Graphics reflects the Ninth Circuit's appreciation of the necessity of requiring plaintiffs to disclose corroborating details so that a court can distinguish an arguably meritorious claim of fraud from a cleverly disguised allegation of "fraud by hindsight." Relying on the Basis Requirement, the court correctly held that a complaint that includes no such details must be dismissed. ${ }^{56}$

52. Under Reform Act $\S 21 D(c), 15$ U.S.C. $§ 78 u-4(c)$ (Supp. IV 1998), a plaintiff and her attorney who quoted a non-existent document in a complaint, in violation of Rule 11(b), could be held liable for all of the defendants' reasonable attorneys' fees and other expenses.

53. Such a third party may, in turn, claim to have seen the document or to have been told of its contents by another.

54. In re Silicon Graphics, Inc. Sec. Litig., 183 F.3d at 985.

55. The court also seemed to appreciate that this problem is pervasive, noting that the district court had taken "judicial notice of five securities class action complaints filed in United States District Courts that contain the same boilerplate allegations of "negative internal reports' ...." Id. at $984 \mathrm{n} .14$; see also In re The Vantive Corp. Sec. Litig., 110 F. Supp. 2d 1209, 1216 (N.D. Cal. 2000) (remarking that the Basis Requirement "is the PSLRA's single most important weapon against pleading fraud by hindsight because it forces plaintiffs to reveal whether they base their allegations on an inference of earlier knowledge drawn from later disclosures or from contemporaneous documents or other facts").

56. See Silicon Graphics, 183 F.3d at 984; see also Heliotrope Gen., Inc. v. Ford Motor Co., 189 F.3d 971, 979 (9th Cir. 1999) (relying on Silicon Graphics's interpretation of the Basis Requirement to grant defendant's motion for judgment on the pleadings with respect to a complaint that the trial court, in a pre-Silicon Graphics decision, had refused to dismiss). 
III

\section{DEFINING "THE REQUIRED STATE OF MIND”}

As noted in Section I, the focus of this article is not on the question of what degree of recklessness constitutes scienter ${ }^{57}$ or whether evidence of motive and opportunity, standing alone, is sufficient to create a strong inference of scienter. However, courts' holdings on those issues provide the substantive context to which the Basis Requirement relates. Those holdings also are relevant to the question of when a plaintiff's allegations should be deemed to give rise to a strong inference of scienter.

Six Courts of Appeals have addressed those questions. ${ }^{58}$ Only one, the Ninth Circuit in Silicon Graphics, has held that, at a minimum, a plaintiff must plead facts sufficient to give rise to a strong inference of "deliberate or conscious recklessness" $" 59$ and that evidence of motive and opportunity, standing alone, never is sufficient to create a strong inference of scienter. ${ }^{60}$ This section argues that Silicon Graphics's holdings on these issues do not differ significantly from the holdings of the First, Sixth, and Eleventh Circuits in Greebel, Comshare, and Avado, respectively. Section V discusses the Second and Third Circuits' holdings on these issues.

Ernst \& Ernst v. Hochfelder ${ }^{61}$ establishes the framework for discussion of what constitutes "the required state of mind" in actions under section 10(b) and Rule 10b-5. The Court interpreted section 10(b) to require proof of "scienter," which it defined as "a mental state embracing intent to deceive, manipulate or defraud." ${ }^{62}$ The Court also reserved the question of "whether, in certain circumstances, reckless behavior" is the equivalent of scienter ${ }^{63}$ and it has twice subsequently reserved that question. ${ }^{64}$

Every Court of Appeals to address the issue has held that proof of recklessness can suffice. ${ }^{65}$ The Courts of Appeals also uniformly have adopted what is often referred to as the Sundstrand definition of recklessness:

$[\mathrm{R}]$ eckless conduct may be defined as a highly unreasonable omission, involving not merely simple, or even inexcusable negligence, but an extreme departure from the

57. Section (b)(2) requires a plaintiff in a private action for money damages to "state with particularity facts giving rise to a strong inference that the defendant acted with the required state of mind." 15 U.S.C. § 78u-4(b)(2) (Supp. IV 1998) (emphasis added).

58. The six decisions, all of which consider these issues in relation to actions under section 10(b) and Rule 10b-5, are Novak v. Kasaks, 216 F.3d 300 (2d Cir. 2000); In re Advanta Corp. Sec. Litig., 180 F.3d 525 (3d Cir. 1999); In re Comshare, Inc. Sec. Litig. 183 F.3d 542 (6th Cir. 1999); In re Silicon Graphics, Inc. Sec. Litig., 183 F.3d 970 (9th Cir. 1999); Bryant v. Avado Brands, Inc., 187 F.3d 1271 (11th Cir. 1999); and Greebel v. FTP Software, Inc., 194 F.3d 185 (1st Cir. 1999).

59. See Silicon Graphics, 183 F.3d at 979.

60. See id.

61. 425 U.S. 185 (1976).

62. See id. at $193 \&$ n. 12 .

63. Id.

64. See Herman \& MacLean v. Huddleston, 459 U.S. 375, 378 n.4 (1983); Aaron v. SEC, 446 U.S. 680, 686 n.5 (1980).

65. See Hollinger v. Titan Capital Corp., 914 F.2d 1564, 1568 n.6 (9th Cir. 1990) (citing cases from 11 circuits). 
standards of ordinary care, and which presents a danger of misleading buyers or sellers that is either known to the defendant or is so obvious that the actor must have been aware of it. ${ }^{66}$

Prior to the passage of the Reform Act, though, courts rarely referred to Sundstrand when considering motions to dismiss. ${ }^{67}$ In some circuits, including the Ninth, the issue did not arise because plaintiffs were allowed to plead state of mind generally, so long as they pled with particularity the circumstances constituting the alleged fraud. ${ }^{68}$ In other circuits, the situation was different. In the Second Circuit - on whose case law the language of section (b)(2) is basedplaintiffs alleging securities fraud were required to plead facts that "give rise to a 'strong inference' that the defendants possessed the requisite fraudulent intent." ${ }^{\prime 69}$ The Second Circuit, however, allowed plaintiffs to satisfy this requirement by alleging facts that either established that the defendants had a motive and the opportunity to commit fraud or that constituted strong circumstantial evidence of reckless or conscious misbehavior. ${ }^{70}$

Close examination of individual Second Circuit decisions makes clear thatperhaps in deference to the statement in Rule 9(b) of the Federal Rules of Civil Procedure that state of mind can be alleged generally ${ }^{71}$ - while the Second Circuit may have "talked the talk," it did not consistently "walk the walk." That is, in numerous cases the Second Circuit allowed plaintiffs to survive motions to dismiss on the basis of allegations that by no stretch of the imagination gave rise to a strong inference that the defendants had acted intentionally or with the degree of recklessness required by Sundstrand. ${ }^{72}$

Time Warner provides a good illustration. Plaintiffs argued that Time Warner had delayed disclosing its plan to raise needed capital through a rights offering in the hope that the delay would allow the company to increase the price

66. Sundstrand Corp. v. Sun Chemical Corp., 553 F.2d 1033, 1045 (7th Cir. 1977) (quoting Franke v. Midwestern Okla. Dev. Auth., 428 F. Supp. 719, 725 (W.D. Okla. 1976)). Sundstrand was the first appellate decision to adopt this definition. See id. at 1044-45. The Seventh Circuit squared its holding with Hochfelder by describing such recklessness as "the functional equivalent of intent." Id. at 1045. The Ninth Circuit recently adopted the Sundstrand definition in Hollinger, 914 F.2d at 1569. Other Circuits also have adopted the standard. See Hackbart v. Holmes, 675 F.2d 1114, 1118 (10th Cir. 1982); SEC v. Carriba Air, Inc., 681 F.2d 1318, 1324 (11th Cir. 1982); Broad v. Rockwell Int'l Corp., 642 F.2d 929, 961-62 (5th Cir. 1981); McLean v. Alexander, 599 F.2d 1190, 1197-98 (3d Cir. 1979); Mansbach v. Prescott, Ball \& Turben, 598 F.2d 1017, $1023-25$ (6th Cir. 1979); Cook v. Avien, Inc., 573 F.2d 685, 692 (1st Cir. 1978); Rolf v. Blyth, Eastman Dillon \& Co., 570 F.2d 38, $46-47$ (2d Cir. 1978).

67. Sundstrand involved an appeal from a judgment entered after trial. Hollinger, the case in which the Ninth Circuit adopted the Sundstrand standard, involved an appeal of a decision granting a motion for summary judgment.

68. See In re Glenfed, Inc. Sec. Litig., 42 F.3d 1541, 1547 (9th Cir. 1994) (en banc) (holding that a plaintiff may aver scienter "simply by saying that scienter existed").

69. Beck v. Mfrs Hanover Trust Co., 820 F.2d 46, 50 (2d Cir. 1987), first set forth this requirement.

70. See, e.g., In re Time Warner, Inc. Sec. Litig., 9 F.3d 259, 268-69 (2d Cir. 1993).

71. See, e.g., Shields v. Citytrust Bancorp, 25 F.3d 1124, 1128 (2d Cir. 1994) (referring to Rule 9(b)'s relaxed specificity requirement for scienter).

72. See Bryant v. Avado Brands, Inc., 187 F.3d 1271, 1286 (11th Cir. 1999); In re Baesa Sec. Litig., 969 F. Supp. 238, 242 n.3 (S.D.N.Y. 1997) (recognizing inconsistencies in the Second Circuit's application of its "strong inference" test); see also Roskoski, supra note 14, at 2273-74 (distinguishing between the pleading "standard" used by the Second Circuit and the two "tests" that court employed to determine whether a plaintiff had met that standard). 
at which it could sell the stock for which the rights would be issued. Defendants ridiculed plaintiffs' claim, pointing out that no matter when Time Warner announced the rights offering, SEC rules would require it to wait several weeks before it could begin to sell stock. During that period, investors surely would incorporate all material information concerning the rights offering into their valuation of Time Warner stock. Consequently, defendants maintained, Time Warner could not reasonably have expected to be able to realize any financial benefit by delaying announcement of its decision to raise capital by means of a rights offering. The Second Circuit acknowledged that defendants' argument had merit but nonetheless reversed the district court's decision dismissing plaintiffs' complaint. ${ }^{73}$ The appellate court observed that because "the laws of economics have not yet achieved the status of the law of gravity, we cannot say, on a motion to dismiss, that plaintiffs cannot prove that a motive existed." ${ }^{14}$

Note the striking disparity between the language of Hochfelder, Sundstrand, and the Second Circuit's "strong inference" test on the one hand and the court's holding in Time Warner on the other. Even one who agreed that, with all reasonable inferences drawn in their favor, plaintiffs arguably had pled facts that might suggest Time Warner hoped that delaying disclosure of its intent to make the rights offering would provide it with some financial benefit still would be forced to concede that the facts pled by plaintiffs were not sufficient to support a strong inference that Time Warner was motivated by an intent to deceive or defraud. $^{75}$ In other words, the court allowed plaintiffs' complaint to survive a motion to dismiss because it contained a weak and implausible claim that Time Warner may have hoped to realize some financial gain.

Silicon Graphics can best be understood as reflecting a rejection of decisions such as Time Warner. The Ninth Circuit concluded that section (b)(2) imposed an obligation to give content to both Hochfelder and Sundstrand when deciding motions to dismiss. Hochfelder and Sundstrand make clear that recklessness is the equivalent of scienter only when it "reflects some degree of intentional or

73. Judge Ralph Winter filed a spirited dissent supporting defendants' claim. See Time Warner, 9 F.3d at 272-75 (Winter, J., dissenting).

74. Id. at 271 (emphasis added).

75. This is especially so because whether Time Warner had a duty to update its prior statements concerning its plans to raise additional capital itself posed a close question. See San Leandro Emergency Med. Group Profit Sharing Plan v. Philip Morris Cos., 75 F.3d 801, 810 (2d Cir. 1996) ("Time Warner went nearly to the outer limit of the line that separates disclosable plans from plans that need not be disclosed ...."); Kalnit v. Eichler, 85 F. Supp. 2d 232, 238-39 (S.D.N.Y. 1999) (holding that complaint did not create a strong inference of scienter because facts defendants allegedly failed to disclose were, at best, of marginal materiality); Weiss, supra note 26, at 688-90 (arguing that whether an issuer clearly has a duty to disclose facts is relevant to inference of scienter).

It also is clear that Time Warner's actions did not involve an "extreme departure from the standards of ordinary care which presents a danger of misleading buyers and seller that is either known to the defendant or is so obvious that [defendants] must have been aware of it." Sundstrand Corp. v. Sun Chem. Corp., 553 F.2d 1033, 1045 (7th Cir. 1977). see Time Warner, 9 F.3d at 271 (explicitly holding that, with respect to Time Warner's alleged nondisclosure of the rights offering, "the complaint cannot be said to adequately plead scienter under the circumstantial evidence of conscious or reckless behavior approach"). 
conscious misconduct." ${ }^{76}$ It follows, Silicon Graphics reasoned, that to meet the requirements of section (b)(2), plaintiffs must plead with particularity facts that "create a strong inference of, at a minimum, 'deliberate recklessness." "77 It also "follows that plaintiffs proceeding under the PSLRA can no longer aver intent in general terms of mere 'motive and opportunity' or 'recklessness,' but rather, must state specific facts indicating no less than a degree of recklessness that strongly suggests actual intent.",78

Comshare adopted a slightly different approach to interpreting section (b)(2). The Sixth Circuit, as did the Ninth Circuit in Silicon Graphics, first reviewed Hochfelder and its earlier endorsement of the Sunstrand definition of recklessness. ${ }^{79}$ The court then held that "[b]ecause it is clear that recklessness, understood as a mental state apart from negligence and akin to conscious disregard, may constitute scienter, we conclude that under the PSLRA, a plaintiff may survive a motion to dismiss by pleading facts that give rise to a 'strong inference' of recklessness." recklessness," but its holding that a plaintiff must plead facts sufficient to give rise to a strong inference of recklessness "akin to conscious disregard," in my opinion, amounts to much the same thing. It is hard to conceive of a set of facts that the Sixth Circuit would view as sufficient to give rise to a strong inference of recklessness "akin to conscious disregard" but that the Ninth Circuit would hold was not sufficient to give rise to a strong inference of "deliberate recklessness."

Comshare's discussion of motive and opportunity also closely tracks Silicon Graphics's discussion of that issue:

[E]vidence of a defendant's motive and opportunity to commit securities fraud does not constitute "scienter" for the purposes of $\S 10 \mathrm{~b}$ or Rule $10 \mathrm{~b}-5$ liability .... While facts regarding motive and opportunity may be "relevant to pleading circumstances from which a strong inference of fraudulent scienter may be inferred," and may, on occasion, rise to the level of creating a strong inference of reckless or knowing conduct, the bare pleading of motive and opportunity does not, standing alone, constitute the pleading of a strong inference of scienter.

At most, this statement reflects a scintilla of difference from Silicon Graphics. Both courts held that facts suggesting motive and opportunity may provide circumstantial evidence of scienter. Silicon Graphics apparently ruled out the possibility that such facts, standing alone, can ever give rise to a strong inference of reckless or knowing misconduct, while Comshare suggested that, "on occasion," facts relating to motive and opportunity may support such an inference.

But such facts will rarely arise. One conceivable example is a situation in which (1) a corporation's top executives held substantial amounts of stock; (2)

\footnotetext{
76. See In re Silicon Graphics, Inc. Sec. Litig., 183 F.3d 970, 977 (9th Cir. 1999).

77. Id.

78. Id. at 979 .

79. See In re Comshare, Inc. Sec. Litig., 183 F.3d 542, 548-50 (6th Cir. 1999).

80. Id. at 550 .

81. Id. at 551 (citation omitted).
} 
those executives sold all or most of their stock shortly after the corporation disclosed "good news" about some aspect of its business; and (3) the corporation shortly thereafter issued "bad news" about the same aspect of its business. The Sixth Circuit might well be prepared to treat these facts, which on their own strongly suggest motive and opportunity, as sufficient to create a strong inference of scienter. Silicon Graphics held that more is required. However, relying on the same facts, the Ninth Circuit might well treat the inconsistency between the two statements, together with their temporal proximity, as circumstantial evidence that the corporation knew or recklessly disregarded that the first statement was false when it was made. Thus, it might well hold, as would the Sixth Circuit, that these facts plus those suggesting motive and opportunity were sufficient to support a strong inference of scienter. ${ }^{82}$

Greebel and Avado endorse Comshare's interpretation of section (b)(2). ${ }^{83}$ Thus, despite minor semantic differences, the substantive definition of scienter adopted by the First, Sixth, and Eleventh Circuits appears to be essentially the same as that adopted by the Ninth.

IV

\section{GREEBEL GIVES CONTENT TO THE STRONG INFERENCE REQUIREMENT}

Greebel is significant for two other reasons. First, it interprets the Basis Requirement in much the same fashion as does Silicon Graphics. Second, it attributes considerable importance to Congress's use of the term "strong inference" in section (b)(2), which leads it to hold that adequately corroborated allegations of fraud-which may well have survived a motion to dismiss in preReform Act days-were properly dismissed because they did not create a strong inference of scienter.

Greebel has a somewhat unusual procedural history. The district court denied defendants' initial motion to dismiss because the complaint included the following "white out" allegation:

82. Note, too, that Comshare and Silicon Graphics adopt the same approach to evaluating claims that sales by insiders support an inference of scienter. Both place on plaintiffs the burden of pleading facts that demonstrate not simply that insiders sold stock at prices influenced by the alleged fraud, but that the insiders' sales, viewed in context, were unusual and suspicious. See Comshare, 183 F.3d at 553; ); In re Silicon Graphics, Inc. Sec. Litig., 183 F.3d 970, 986 (9th Cir. 1999) ("Among the relevant factors to consider are: (1) the amount and percentage of shares sold by insiders; (2) the timing of the sales; and (3) whether the sales were consistent with the insider's prior trading history.").

83. See Greebel v. FTP Software, Inc., 194 F.3d 185, 197 (1st Cir. 1999) ("Our view of [section (b)(2)] is thus close to that articulated by the Sixth Circuit."); Bryant v. Avado Brands, Inc., 187 F.3d 1271, 1283 (11th Cir. 1999).

[W]e are in basic agreement with the Sixth Circuit; we hold that the Reform Act does not prohibit the practice of alleging scienter by pleading facts that denote severe recklessness, the standard previously approved of by this Circuit ... but we also hold that the Reform Act does not codify the 'motive and opportunity' test formulated by the Second Circuit." Id. (citation omitted).

Greebel also takes essentially the same approach to allegations of insider trading. See Greebel, 194 F.3d at 206-07. Avado does not explicitly address insider trading. 
During the third quarter of 1995, the defendants became aware that sales were drastically below internal forecasts and performance goals and instructed FTP's sales force to induce distributors to accept additional FTP product with the promise that the distributors had the right to return any product that they failed to sell. Distributors sent in their orders to FTP noting that they were entitled to return any unsold product. Aware that recognizing revenue where the right of return existed was improper, the defendants instructed FTP's sales force to "white out" this notation on the distributors' order forms in order to prevent FTP's auditors from discovering the contingent nature of the sales. A material percentage of these purported sales were either returned to the Company or remain with distributors, but have not been paid for. ${ }^{84}$

Following the district court's decision, defendants and plaintiffs made disclosures pursuant to Rule 26 of the Federal Rules of Civil Procedure. Defendants demanded that plaintiffs produce documents or witnesses to support this "white out" allegation. ${ }^{85}$ Plaintiffs countered by asking the court to allow them to conduct discovery of FTP customers who they believed had submitted the purchase orders on which notations of a right to return allegedly had been "whited out." " The district court rejected plaintiffs' request. Although it had allowed plaintiffs to survive defendants' motion to dismiss on the basis of their uncorroborated "white out" allegations, the court now told plaintiffs: "You have to know what your case is about before you bring it." ${ }^{\text {7 }}$ Because plaintiffs" attorney indicated that the "white out" allegation may have been based entirely on the hearsay testimony of one witness, the court ordered plaintiffs to advise defendants of the name of that and any other percipient witnesses and the substance of their testimony. ${ }^{88}$ Plaintiffs thereafter acknowledged that the "white out" allegation was based on the testimony of Trudy Nichols, a former FTP employee who plaintiffs' attorney advised the court had been told about the alleged "whiting out" by current FTP employees. ${ }^{89}$ Plaintiffs, however, were unable to produce Ms. Nichols for a deposition as she was either unavailable or unwilling to testify..$^{90}$

84. Plaintiffs' Second Amended Complaint II 45, Greebel v. FTP Software, Inc., 182 F.R.D. 370 (D. Mass. 1998), received as an attachment to a facsimile dated Aug. 2, 1999, from Sanford Dumain, Esq., counsel for plaintiffs, to Elliott Weiss, in which Mr. Dumain identified paragraph 45 as "the only specific reference to "white out" in the Second Amended Complaint. The district court did not issue an opinion explaining its denial of defendants' initial motion to dismiss. At a subsequent hearing, the court stated that it was the white out allegation "that saves [plaintiffs] from the Motion to Dismiss." Appellant's Brief App., vol. 5, at 1190, Greebel (No. 98-2194) [hereinafter Greebel Appendix] (transcript of hearing, Apr. 29, 1997); see also Greebel v. FTP Software, Inc., 182 F.R.D. 370, 373 (D. Mass. 1998). At the hearing on defendants' initial motion to dismiss, defendants' counsel pressed the court to dismiss the complaint on grounds other than plaintiffs' failure to specify the basis for their "white out" allegation. See Greebel Appendix, supra, at 1147-49 (transcript of hearing, Feb. 4, 1997).

85. See Greebel Appendix, supra note 84, at 1187 (transcript of hearing, Apr. 29, 1997).

86. See id. at 1193-94.

87. Id. at 1191. The court added: "I mean, filing a lawsuit should be the last thing you do, not the first thing you do." Id.

88. See id. at 1196. At a hearing held six weeks later, the court reiterated this instruction after plaintiffs produced a list of seven witnesses, six of whom were defendants. See id. at 1200 (transcript of hearing, June 19, 1997).

89. See id. at 1210-11 (transcript of hearing, July 31, 1997).

90. See Greebel, 182 F.R.D. at 372. 
That led defendants to move for partial summary judgment on plaintiffs' "white out" claim and to renew their motion to dismiss the balance of the complaint. The district court granted both motions ${ }^{91}$ and also denied plaintiffs' request that it consider evidence plaintiffs had obtained from files FTP had disclosed, reasoning, in effect, that such evidence constituted fruit from a poisoned tree. $^{92}$ Plaintiffs appealed all three rulings to the First Circuit.

Greebel first held that the Basis Requirement in section (b)(1) "is congruent and consistent with the pre-existing standards of this circuit." ${ }^{93}$ The court noted, in particular, that under Rule 9(b), "this court has required plaintiffs who bring their claims on information and belief to 'set forth the source of the information and the reasons for the belief.", ${ }^{94}$ These "strict pleading requirements under Rule 9(b)," the court continued, "are, in our view, consistent with the PSLRA." 95

Turning to section (b)(2), Greebel held that the language of the Act supports three conclusions. First, "[C]ongress plainly contemplated that scienter could be proven by inference, thus acknowledging the role of indirect and circumstantial evidence." ${ }^{\prime 6}$ Second, "the words of the Act neither mandate nor prohibit the use of any particular method to establish an inference of scienter." ${ }^{\prime 97}$ Third, and most significantly, section (b)(2) effectively overrides Conley v. Gibson. The court stated:

[C]ongress has effectively mandated a special standard for measuring whether allegations of scienter survive a motion to dismiss. While under Rule 12(b)(6) all inferences must be drawn in plaintiffs' favor, inferences of scienter do not survive if they are merely reasonable, as is true when pleadings for other causes of action are tested by motion to dismiss under Rule 12(b)(6). Rather, inferences of scienter survive a motion to dismiss only if they are both reasonable and "strong" inferences.

The court then observed: "In the guise of tinkering with procedural requirements, Congress has effectively, for policy reasons, made it substantively harder for plaintiffs to bring securities fraud cases, through the 'strong inference' of

91. See id. at 373, 376. The court dismissed the complaint with prejudice. See id. at 376.

92. See id. ("Plaintiffs would not have discovered the additional evidence but for the inclusion of the white-out claim, which ... has since turned out to be groundless.").

93. Greebel v. FTP Software, Inc., 194 F.3d 185, 193 (1st Cir. 1999).

94. Id. at 194 (quoting Romani v. Shearson Lehman Hutton, 929 F.2d 875, 878 (1st Cir. 1991)). The court also quoted Hayduk v. Lanna, 775 F.2d 441, 444 (1st Cir. 1985): "Even where allegations are based on information and belief, supporting facts on which the belief is founded must be set forth in the complaint. And this holds true even when the fraud relates to matters peculiarly within the knowledge of the opposing party." Greebel, 194 F.3d at 193.

95. Greebel, 194 F.3d at 194. Two other circuits, in decisions involving claims of securities fraud filed before the Reform Act became effective, also had interpreted Rule 9(b) to require plaintiffs to specify the basis for allegations made on information and belief. See Parnes v. Gateway 2000, Inc., 122 F.3d 539, 550 (8th Cir. 1997); In re Healthcare Compare Corp. Sec. Litig., 75 F.3d 276, 281-82 (7th Cir. 1996).

96. Greebel, 194 F.3d at 195 (citation omitted).

97. Id.

98. Id. at 195-96 (emphasis added) (citation omitted). 
scienter requirement." ${ }^{99}$ Finally, the court reiterated: "The most salient feature of the PSLRA is that whatever the characteristic pattern of the facts alleged, those facts must now present a strong inference of scienter. A mere reasonable inference is insufficient to survive a motion to dismiss." 100

Having established a framework for analysis, Greebel provided a concrete example of the kind of allegations that may create a strong inference of scienter when it stated that "[i]f adequately supported, claims that management deliberately altered company records to hide material information from company auditors could well create" a strong inference of scienter. ${ }^{101}$ In the case before it, though, because "plaintiffs could not produce admissible evidence to support the white-out allegations, [the court] disregard[ed them]."102

The terms the court used to state this holding raise an important question: Did the court mean to suggest that only "admissible evidence" can constitute "adequate support" for allegations of securities fraud? In my view, that is not how Greebel should be interpreted. The question the court addressed was whether the district court had properly granted defendants' motion for partial summary judgment on the "white out" claim. To survive that motion, plaintiffs had to produce evidence that supported every essential element of the claim. The court's reference to "admissible evidence" thus makes sense in the context of a motion for summary judgment, but it does not imply that a plaintiff must support every essential allegation in her complaint with "admissible evidence."

Greebel does make clear that the district court should have focused on whether plaintiffs had described the source of information on which they based their "white out" allegations when it ruled on defendants' initial motion to dismiss. Had the district court done so, it presumably would have granted defendants' motion because plaintiffs did not describe in their complaint the facts on which those allegations were based. Had plaintiffs then disclosed that the "white out" allegations were based entirely on the hearsay statement of one former FTP employee, ${ }^{103}$ Greebel establishes that the district court still should have dismissed the complaint on the ground that those allegations, considered in light of the facts on which they were based, do not have sufficient probative value to give rise to a strong inference of scienter.

Greebel's treatment of plaintiffs" "warehousing allegations"-their claim that, during the class period, FTP recorded as "sales" shipments it made to a warehouse (rather than to customers) and later accepted back as returned

99. Id. at $196 \mathrm{n} .9$. The court also discusses the fact that "[t]he device of effecting policy-based change through adjustments in procedural or evidentiary rules is not new, nor is it unique to Congress." Id.

100. Id. at 196 (emphasis added).

101. Id. at 201 .

102. $I d$. at 202 .

103. Plaintiffs' counsel, Mr. Dumain, first told the court: "I will tell you specifically she will testify that she was told it happened, and that she will identify the persons." Greebel Appendix, supra, note 83, at 1209 (transcript of hearing, Apr. 29, 1997). Mr. Dumain later suggested that "every time we have asked her to tell us who at the company" spoke to her, Ms. Nichols was unwilling to do so. Id. at 1214. 
goods-supports this conclusion. ${ }^{104}$ As with the "white out" claims, the court suggested that these allegations, if true, "are very serious." ${ }^{105}$ But the court then dismissed these allegations because, considering the facts on which they are based, they "are not enough to support a strong inference of scienter."

The court's discussion of the "white out" and "warehousing" allegations highlights a key aspect of the relationship between section (b)(1) and section (b)(2). Under section (b)(1), a plaintiff must disclose the basis for each allegation made on information and belief. The nature and quality of the factual basis for each such allegation then becomes relevant to the court's determination as to whether the plaintiff has pled facts sufficient to give rise to a strong inference of scienter.

Greebel establishes that a hearsay statement by one person with no first hand information as to the relevant facts, standing alone, generally will not suffice. Neither will facts suggesting a corporation engaged in some improper practice before the start of the class period. ${ }^{107}$ Other claims, based on other facts, no doubt will give rise to more difficult questions.

Greebel's analysis of plaintiffs' other allegations, concerning "channel stuffing" and contingent sales, illustrate the importance of the court's holding that to satisfy section (b)(2), a plaintiff must plead facts that give rise to a strong inference of scienter. The court avoided the sticky question of whether the district court should have considered the arguably "tainted" evidence plaintiffs obtained through discovery by holding that even had plaintiffs incorporated that additional evidence into their complaint, they still failed to plead facts sufficient to create a strong inference of scienter. ${ }^{108}$

The court quickly dispensed with the "channel stuffing" "109 allegations. It treated them as adequately corroborated and noted that evidence of channel stuffing "has some probative value." 110 But, the court continued, "that value is

104. See Greebel, 194 F.3d at 202.

105. Id.

106. $I d$.

107. See id.

108. See id., 194 F.3d at 204. I term the question "sticky" because the court had no easy way to answer it. If Greebel had held that the district court should have considered that evidence, plaintiffs who knew they could not satisfy the Basis Requirement might have been tempted to "manufacture" bogus sources for critical allegations they made on information and belief, in the hope that through discovery, they would be able to find evidence of fraud (and thus avoid sanctions under Rule 11). On the other hand, if Greebel had concluded that the district court properly refused to consider evidence plaintiffs had discovered, and that that evidence created (or might have created) a strong inference of scienter, the court effectively would have acknowledged that the Reform Act may shield from prosecution likely instances of securities fraud. Cf. In re South Pac. Funding Corp. Sec. Litig., 83 F. Supp. 2d 1172 (D. Or. 1999) (denying renewed motion to dismiss and allowing plaintiffs to rely on fruits of discovery obtained after court's original decision denying motion to dismiss, which was inconsistent with but issued prior to Silicon Graphics).

109. "'Channel stuffing' means inducing purchasers to increase substantially their purchases before they would, in the normal course, otherwise purchase products from the company. It has the result of shifting earnings into earlier quarters, quite likely to the detriment of earnings in later quarters." Greebel, 194 F.3d at 202.

110. Id. at 203. 
weak. Unlike altering company documents, there may be any number of legitimate reasons for attempting to achieve sales earlier. Thus, [plaintiffs' channel stuffing evidence] does not support a strong inference of scienter." court underlined the significance of the "strong inference" requirement by noting that "[b]efore the PSLRA, a number of courts gave weight to channel stuffing allegations in refusing to grant stays of discovery or motions for dismissal or summary judgment." 112

Greebel's treatment of plaintiffs' claims concerning FTP's contingent sales had a similar effect. Plaintiffs produced evidence of one transaction that FTP booked as a sale even though the customer had an unqualified right to return the product within sixty days. The court pointed out that under generally accepted accounting principles ("GAAP"), a seller is permitted to treat such a transaction as a sale if it establishes a reasonable reserve for returns. Plaintiffs pled no facts indicating FTP failed to establish an adequate reserve, leading the court to conclude:

Without any information on FTP's experience with past return rates, the size of its reserve for returns, or how the reserve changed over time, it is difficult to infer that FTP's revenue recognition decisions were unreasonable enough to violate GAAP, or that they give rise to a strong inference of scienter. ${ }^{113}$

The court acknowledged that in September 1995, FTP probably should not have booked as a sale a $\$ 1.14$ million order placed on September 28 for software that documents indicated FTP had not yet fully developed. But, the court argued, "[i]t is a leap from there to a strong inference of scienter." 114 Even when considered together with another clearly contingent order for $\$ 416,325$ that FTP also booked as a sale in September, the court pointed out that plaintiffs' additional evidence indicates only that FTP improperly recognized between $\$ 416,000$ and $\$ 1.55$ million in revenue in a quarter in which its total revenues were $\$ 37.1$ million. This, Greebel holds, "do[es] not support a strong inference of scienter. It is equally possible to conclude that FTP made some incorrect accounting decisions regarding a limited number of transactions. Seeing fraud ... requires too great of an inferential leap."

111. Id.

112. Id. at $203 \mathrm{n} .16$ (citing cases). Greebel contrasted these with a post-PSLRA district court decision, Lirette v. Shiva Corp., 27 F. Supp. 2d 268, 282-83 (D. Mass. 1998), which holds that allegations of channel stuffing are not sufficient to create a strong inference of scienter.

113. Greebel, 194 F.3d at 205. As concerns another set of transactions, where plaintiffs submitted documents indicating that FTP improperly booked a $\$ 138,078$ transaction as a sale and improperly booked as sales two transactions in September totaling $\$ 548,192$, which remained largely unpaid as of December 31, 1995, Greebel appears to disregard the first as inconsequential and holds as to the others that "[ $t]$ he mere existence of an overdue receivable does not support an inference that the original transaction was booked as a sale in violation of GAAP." See id. at 204.

114. Id.

115. Id. at 206 (footnote omitted). The court contrasts this with a case on which plaintiff produced evidence of a questionable sale that accounted for $\$ 5$ million of a corporation's $\$ 9$ million in quarterly revenues. See id. at 206 n.18. 
Finally, ${ }^{116}$ the court acknowledged that the Reform Act's new pleading requirements dictated the result it reached:

The difficult and different balance the [Reform] Act now requires-testing allegations before little or no discovery, but holding plaintiffs to a strong inference of scienter standard-has been honored in this case. Plaintiffs did not have enough weight on their side of the balance to meet the requirements of the Act, and so we affirm the dismissal. ${ }^{11}$

\section{V}

\section{Two IMPORTANT PENDING CASES}

Two cases with different procedural postures currently pending in the Second and Third Circuits could provide important clues as to whether those courts will similarly honor Congress's intent in their interpretation of the PSLRA. In Novak v. Kasaks ${ }^{118}$ the Second Circuit vacated and remanded a district court decision dismissing a securities fraud complaint. Novak's significance is unclear. It could reflect the Second Circuit's resolve to interpret sections (b)(1) and (b)(2) in a considerably more relaxed fashion than Silicon Graphics and Greebel, or it could represent no more than a holding that plaintiffs are not required to include in their complaints the names of the individuals who were the sources of information on which plaintiffs based their allegations.

The district court wrongly denied defendants' motion to dismiss in In re Cell Pathways, Inc. Securities Litigation. ${ }^{119}$ The district court's opinion, written after defendants petitioned the Third Circuit for a writ of mandamus, calls attention to that petition and thus increases Cell Pathways' potential significance. ${ }^{120}$

\section{A. Novak v. Kasaks}

Novak involves an amalgam of issues similar to those addressed in Silicon Graphics and Greebel. Suit was brought on behalf of all persons who purchased AnnTaylor Stores Corporation ("AnnTaylor") stock between February 3, 1994, the date on which AnnTaylor announced its FY 1994 results, and May 4, 1995, the date on which AnnTaylor unexpectedly announced reduced same-store sales and sharply lower earnings for the first quarter of FY $1995 .{ }^{121}$ AnnTaylor

116. The court also held that plaintiffs' allegations relating to insider trading did not support a strong inference of scienter. See id. at 206-07.

117. Id. at 207.

118. 216 F.3d 300 (2d Cir.), cert. denied, 121 S. Ct. 567 (2000). The petition for certiorari was filed and denied after this article was written. Other developments subsequent to September 1, 2000, are discussed infra in note 186.

119. In re Cell Pathways, Inc., Fed. Sec. L. Rep. (CCH) II 91,001 (E.D. Pa. June 20, 2000).

120. See id. at *1-2; Petition of Cell Pathways, Inc., Bob Towarnicki and Rifat Pamukcu for Writ of Mandamus, In re Cell Pathways, Inc., Fed. Sec. L. Rep. (CCH) II 91,001 (E.D. Pa. June 20, 2000) (No. 99-752) [hereinafter "CPI Petition"].

121. See Amended Complaint for Violation of the Securities Exchange Act of 1934 at II 1, Novak v. Kasaks, 26 F. Supp. 2d 658 (S.D.N.Y. 1998) (No. 96CIV3073) [hereinafter Novak Amended Complaint]. AnnTaylor's fiscal year ended on the Saturday closest to January 31 of the following calendar year, so that FY 1994 ended on January 28, 1995. See id. II 9(d). 
blamed its problems on a weak retail environment and on merchandising problems with its spring line of clothing. ${ }^{122}$ The market reacted quickly: The price of AnnTaylor stock, which had declined substantially during the previous month, dropped an additional twenty-five percent on May $5 .{ }^{123}$

1. The District Court's Decisions. Plaintiffs' original complaint, filed almost one year later, ${ }^{124}$ consisted largely of uncorroborated allegations to the effect that AnnTaylor and certain of its executives had engaged in "an elaborate 'Box \& Hold' scheme" ${ }^{2125}$ in which they "knowingly and intentionally issued financial statements that overstated AnnTaylor's financial condition by accounting for inventory that they knew to be obsolete and nearly worthless at inflated values

122. See Jennifer L. Brady \& Thomas J. Ryan, First Quarter Slump for The Limited, Nordstrom, Ann Taylor, WOMEN's WeAR DAILY, May 10, 1995, available in WL 8304453. AnnTaylor had turned in a standout performance in the highly competitive women's fashion industry in FY 1994. See id.

123. See Novak Amended Complaint, supra note 121, II 92.

124. See Complaint for Violation of the Securities Exchange Act of 1934, Novak v. Kasaks, 997 F. Supp. 425 (S.D.N.Y. 1998) (No. 96CIV3073), available at (visited Oct. 1, 2000) <http://securi ties.stanford.edu/complaints/anntaylor/96cv03073/001.html> [hereinafter Novak Original Complaint]. Plaintiffs sued both AnnTaylor and associated individuals ("AnnTaylor defendants") and Merrill Lynch and associated individuals ("Merrill Lynch defendants"). The Merrill Lynch defendants eventually settled with plaintiffs for $\$ 3$ million, which represents a very small percentage of the damages claimed. See Settlements: AnnTaylor Stores Corporation, SECURITIES ClASS ACTION AlERT, Nov. 1999 , at 28 .

125. See Novak Amended Complaint, supra note 121, II II 31-32. The amended complaint described the alleged "Box \& Hold" scheme as follows:

31. Prior to and throughout the Class Period, AnnTaylor had accumulated huge amounts of excessive merchandise inventories beyond the levels internally budgeted or planned for by defendants which had not been marked-down and disposed of through the Company's stated markdown and Factory store clearance process. To hide this serious problem from the marketplace and the investing public and to avoid large write-downs and liquidation of the excessive inventories and thereby artificially inflate AnnTaylor's reported profits and margins and future earnings estimates, defendants engaged in an elaborate "Box \& Hold" scheme, whereby millions of dollars of excessive and nearly worthless inventories were stored in two secret warehouse locations throughout the Class Period. Rather than write-down and liquidate these excessive inventories which had not been sold (and which AnnTaylor's Factory stores would not accept for sale due to their own excess inventory problems), prior to the start of the Class Period, defendants set up a procedure whereby the inventory would be "Boxed" in cartons and removed from AnnTaylor stores and shipped to two secret warehouses to "Hold" for later disposition. As part of this scheme, "Box and Hold" labels were sent to each AnnTaylor store which were affixed to the outside of the cartons that were shipped to the warehouses on a regular basis. This procedure also alleviated the pressure on the individual AnnTaylor stores which were overburdened with inventories and did not have the space to store out of season and outdated merchandise.

32. Initially, and before the start of the Class Period, AnnTaylor's insiders hoped that the Company would be able to dispose of and sell such excess inventory later, through reduced prices at AnnTaylor Factory (clearance) stores. However, this never happened. Box \& Hold inventories grew out of control by the start of the Class Period, with AnnTaylor having accumulated, approximately $\$ 6$ million of excessive and nearly worthless Box \& Hold inventory by February 2, 1994, including out-of-season goods from as far back as 1992! This Box \& Hold inventory (which continued to grow at an alarming rate) remained inside of the Box \& Hold warehouses throughout the Class Period, without write-down or disposition, in part because the AnnTaylor Loft and Factory stores ... had their own serious problems with excess inventories and refused to accept excess AnnTaylor stores inventory for clearance sales.

Id. IIII 31-32. 
and by deliberately failing to adhere to the Company's publicly stated markdown policy." 126

The district court dismissed plaintiffs' original complaint, holding that it "fail[ed] to allege with sufficient specificity that at the time the AnnTaylor defendants made favorable statements to securities analysts, they were aware that much of their inventory was worthless or seriously overvalued, or were reckless as to whether that was the case." ${ }^{127}$ The court also pointed out that while plaintiffs' claims focused on the alleged "Box \& Hold" scheme, "[t]he term 'boxand-hold' is nowhere defined in the complaint." 128 The court observed that plaintiffs, instead of providing details to support the allegations as required by Rule 9(b), relied on "conclusory language" and "hot words."

The court also addressed plaintiffs' failure to satisfy the Basis Requirement, holding that plaintiffs' umbrella description of the basis for their claims ${ }^{130}$ "provides none of the required facts underlying the complaint's allegations as to the information that was available to the individual defendants, nor does it direct the Court to where those facts might be found"; ${ }^{131}$ that the district court in Silicon Graphics rejected an identical paragraph as insufficiently specific; ${ }^{132}$ and that plaintiffs "also provide no basis for their allegation that "throughout the Class Period, AnnTaylor was falsifying and artificially inflating its reported net income and earnings per share via its "box-and-hold" scheme to hide excess, slow-moving and/or unsalable inventory and avoid writing off that inventory." $" 133$

126. Novak v. Kasaks, 216 F.3d 300, 304 (2d Cir. 2000).

127. Novak, 997 F. Supp. at 431. The court added,

[t]his deficiency is particularly striking where the target of the allegations is conceded to be "a specialty retailer of women's apparel, shoes, and accessories;" a company engaged in a business that is affected by considerations of fashion and taste. In effect, AnnTaylor was necessarily involved in the generation of inventory based upon predictions as to product that was Id. expected to sell at a particular time or season.

128. Id. The court also observed that

[c] ounsel for the AnnTaylor defendants stated at oral argument that AnnTaylor does, in fact, transfer merchandise to warehouses on a seasonal basis, that some of this merchandise is ultimately sold at less than full price, and that the value of this inventory is written down on the books as markdowns are taken.

Id. at 432 .

129. Id. at 421 (citations to original complaint omitted).

130. Plaintiffs asserted that the allegations in the original complaint were "based upon the investigation of their counsel, which included a review of AnnTaylor's SEC filings, securities analysts reports and advisories about the Company, press releases issued by the Company, media reports about the Company and discussions with consultants ...." Novak Original Complaint, supra note 124, II 138. I refer to this as an "umbrella description" because plaintiffs made no effort to tie specific allegations to specific sources.

131. Novak, 997 F. Supp. at 431.

132. See id. The resemblance may not be coincidental, as plaintiffs in both cases were represented by Milberg Weiss Hynes Bershad \& Lerach, LLP.

133. Id. 
Plaintiffs thereafter filed an amended complaint. ${ }^{134}$ They added to their listing of the categories of information on which their claims were based " ${ }^{135}$ "internal AnnTaylor documents obtained through plaintiffs' investigation; and documents produced by various non-parties to this litigation, as well as confidential communications with certain former AnnTaylor employees and independent consultants." 136 Plaintiffs also made additional, arguably significant, substantive allegations, apparently based on these newly listed sources.

Plaintiffs now alleged that an AnnTaylor internal document, a "Weekly Report" dated January 22, 1996, "demonstrates that . . over six months after the end of the Class period," thirteen percent of the "apparel units" and twenty percent of the "shoe units," "consist[ing] primarily of 1993 and 1994 Class Period merchandise" and having a reported value of $\$ 14$ million, which was equal to fourteen percent of the publicly reported value of AnnTaylor's inventory as of January 28, 1996. ${ }^{138}$ Plaintiffs further asserted that the "actual value" of the January 22, 1996 "Box \& Hold" inventory "was nearly zero" but did not attribute this claim to the January 22, 1996 Report or to any other source. ${ }^{139}$ They also alleged that similar Weekly Reports with the same format as the January 22, 1996 Report were distributed to AnnTaylor's senior management every Monday during the class period. ${ }^{140}$

Finally, plaintiffs alleged in paragraph 35 of their amended complaint that during the class period there were numerous discussions, involving three senior AnnTaylor executives named as individual defendants and other AnnTaylor executives, in which "many AnnTaylor executives demanded that [these individual defendants] end the Box \& Hold practice as it made no business sense and was growing out of control." ${ }^{141}$ The response of the three individual defendants, plaintiffs claimed,

was that AnnTaylor could not "afford" to eliminate or write-down the Box \& Hold inventory because doing so would "kill" the Company's reported financial results and/or profit margins and damage the Company on "Wall Street"... [and that each individual defendant] knew, at all relevant times, that this inventory due to its age and condition was nearly worthless and could not and would not be sold at its stated value. $^{142}$

Defendants renewed their motion to dismiss, which the district court subsequently granted. ${ }^{143}$ The court held that plaintiffs' additions failed to correct the deficiencies in the original complaint, "or even to address them in any meaning-

134. The district court's first decision granted plaintiffs 30 days to re-plead their case. See id. at 435 .

135. See text supra note 130.

136. Novak Amended Complaint, supra note 121, at introductory par. (numbers in listing omitted).

137. Id. If 37 (emphasis in original).

138. Id.

139. Id.

140. See id. II 34.

141. Id. II 35 .

142. $I d$.

143. See Novak v. Kasaks, 26 F. Supp. 2d 658, 660 (S.D.N.Y. 1998). 
ful way." the AnnTaylor defendants knew that the box-and-hold inventory 'was nearly worthless and could not and would not be sold at its stated value." 145 Accepting arguendo plaintiffs' claim that AnnTaylor's top managers received a report each Monday detailing AnnTaylor's inventory, including Box \& Hold inventory "subdivided into seasonal lines (e.g., 'Fall 92')," "146 the court pointed out that "these documents, if they exist, do nothing more than confirm a fact already acknowledged by AnnTaylor-that AnnTaylor held merchandise in warehouses and ultimately marked down this merchandise." ${ }^{147}$

Similarly, the district court concluded that plaintiffs' allegations concerning the January 22, 1996 Weekly Report did not advance their cause. First, the court questioned the relevance of "a document describing the situation which existed, as plaintiffs emphatically put it, over six months after the end of the Class Period." 148 The court then noted that, "[b]y plaintiffs' own count, there were 460,230 units of warehoused inventory. Dividing this number into $\$ 14$ million results in an average value of $\$ 30$ per unit. Plaintiffs offer no explanation as to why that number is an excessive average valuation for upscale clothing and shoes." 149 Finally, and "perhaps most importantly," the court highlighted the fact that "plaintiffs offer no support for the allegation that the value of the box and hold inventory was 'nearly zero,' nor do they attempt to demonstrate why $\$ 14$ million was not a proper value to assign to the inventory." ${ }^{150}$ In sum, the court suggested that even if plaintiffs had been able to show that at some time during the class period, AnnTaylor held Box \& Hold inventory in amounts identical to those it allegedly held on January 22, 1996, the court would not, without more, find those facts sufficient to create a strong inference of scienter. In this respect, the district court's approach was much the same as that the First Circuit subsequently adopted in Greebel.

That leaves the allegations in paragraph 35, which the district court caustically described as "an excellent example of the improper pleading which leads the Court once again to dismiss the complaint." 151 But here the court's reasoning, while fundamentally sound, may not have been sufficiently nuanced. The court first faulted plaintiffs for not identifying the individual "former employ-

144. Id.

145. Id. at 661 (citation to amended complaint omitted).

146. Id.

147. Id.

148. Id. at 662. The court's statement that this information has "no relevance" may go too far. It seems more accurate to say, as the court did in Greebel, that in light of the seasonality of AnnTaylor's business and of its sensitivity to fashion trends, the fact that AnnTaylor had this amount of Box \& Hold inventory eight months after the end of the class period might have some probative value, "[b]ut that value is weak." Greebel v. FTP Software, Inc., 194 F.3d 185, 203 (1st Cir. 1999); see supra text accompanying notes $111-112$.

149. See Novak, 26 F. Supp. $2 d$ at 662 . The court also observed that it "is unable to ascertain the meaning" of plaintiffs' claim that the January 22, 1996 Box and Hold inventory consists "primarily" of 1993 and 1994 class period merchandise. Id.

150. Id.

151. Id. at 661 . 
ees" on whose reports it assumed paragraph 35 was based, a failure that it said "ignores the clear mandate of the Court in our earlier opinion, and is contrary to the particularity requirements of [section (b)(1)]." ${ }^{152}$ The court was correct insofar as it held that plaintiffs did not satisfy the Basis Requirement with respect to paragraph 35, because nowhere in the amended complaint did plaintiffs identify the facts on which they based the allegations in that paragraph. ${ }^{153}$ But the court was on less solid ground to the extent that it refused to credit the allegations in paragraph 35 solely because plaintiffs did not name the former employees on whom they relied. It was not clear then, and is not clear now, whether a plaintiff must name all of her testimonial sources to satisfy the Basis Requirement. ${ }^{154}$

The court also found that the allegations in paragraph 35, if credited, would reflect "nothing more than disagreement by certain AnnTaylor executives with business decisions made by the AnnTaylor defendants." 155 But close reading suggests that plaintiffs reasonably could contend that paragraph 35 suggests the three individual defendants rejected demands that they write down the Box \& Hold inventory because they were concerned that such action would negatively affect the price of AnnTaylor stock. Plaintiffs' claim then would appear to be analogous to the "white out" claim that Greebel held could (if adequately corroborated) create a strong inference of scienter. ${ }^{156}$

But while the premise of this argument seems correct, the conclusion is flawed. Even if the allegations in paragraph 35 arguably support a reasonable inference that the individual defendants acted with scienter, they fall far short of compelling such an inference. Whiting out notations on purchase orders to deceive a company's auditors can serve no legitimate purpose. In contrast, even were the court prepared to accept that the conversations described in paragraph 35 actually occurred, it still could read that paragraph to suggest no more than that the individual defendants expressed both concern about the impact that writing down the value of Box \& Hold inventory would have on the price of AnnTaylor's stock and a good faith belief that writing down that inventory would be premature. ${ }^{157}$

Such an interpretation may be what the court intended to suggest when it stated that "plaintiffs offer absolutely no support for the conclusory, unsupported and inflammatory allegation that the AnnTaylor defendants knew the box and hold inventory to be "nearly worthless." 158 Plaintiffs might respond that a reasonable implication of the allegations in paragraph 35 is that some

152. Id.

153. See, e.g., In re Silicon Graphics, 183 F.3d 970, 985 (9th Cir. 1999); Greebel, 194 F.3d at 193.

154. Neither Silicon Graphics or Greebel explicitly sets forth such a requirement.

155. Novak, 26 F. Supp. $2 \mathrm{~d}$ at 661.

156. See Greebel, 194 F.3d at 201.

157. The court might also criticize paragraph 35 on the ground that plaintiffs do not attribute specific statements to identified defendants. See infra note 179.

158. Novak, 26 F. Supp. $2 d$ at 661 . Plaintiffs do not expressly claim that any participant in the alleged discussions admitted that the Box \& Hold inventory was nearly worthless. 
AnnTaylor executives expressed concern that Box \& Hold inventory had grown so large that AnnTaylor would have difficulty selling it at a profit. But it does not follow that the defendant executives shared (or recklessly disregarded the basis for) the other executives' belief. Thus, plaintiffs' allegations, if credited, still are not sufficient to support a strong inference that the defendant executives acted with an intent to deceive or defraud.

In short, the district court could have rejected the allegations in paragraph 35 in a manner consistent with the principles subsequently articulated in Silicon Graphics and Greebel. ${ }^{159}$ The reasons that the court advanced for rejecting those allegations, however, rendered its decision vulnerable to criticism. Plaintiffs focused on those reasons when they appealed to the Second Circuit.

2. The Second Circuit's Decision. Rather than confining itself to these issues, the Second Circuit used Novak as a vehicle to discuss both general pleading issues under sections (b)(1) and (b)(2) and the specific issues Novak raised. ${ }^{160}$ Unfortunately, the court's discussion of both sets of issues is confusing and contradictory.

a. Pleading standards under the Reform Act. The court observed that "[t]he landscape of securities fraud litigation has been transformed in recent years by the passage of the PSLRA." ${ }^{161}$ After briefly reviewing the history of the Reform Act and quoting sections (b)(1) and (b)(2), the court noted that a simple restatement of the Second Circuit's oft-quoted, two-part strong inference test "conceals the complexity and uncertainty that often surround its application" 162 and acknowledged that "different courts applying the pleading standard to differing factual circumstances may reach seemingly disparate results." 163 The court noted, however, that "we discern some basic patterns in our [pre-Reform Act] case law under $\S 10(\mathrm{~b})$ and Rule 10b-5 that help to provide substance to the general language of the standard itself."164

Novak's summary of the law concerning motive and intentional misconduct is straightforward ${ }^{165}$ unlike its discussion of recklessness. After reiterating that the Second Circuit adopted a general definition of recklessness based on Sund-

159. Greebel also makes clear that had plaintiffs disclosed that they based paragraph 35 on hearsay statements by a former AnnTaylor employee, or similarly unreliable facts, the court would have been justified in granting defendants' motion to dismiss. See Greebel, 194 F.3d at 191.

160. The Second Circuit had previously characterized, without discussion, the Reform Act's pleading requirement as embodying that court's pre-Reform Act case law. See Press v. Chemical Invest. Servs. Corp., 166 F.3d 529, 538 (2d Cir. 1999). Novak characterizes Press's statement as dicta. See No$v a k, 216$ F.3d at 310.

161. See Novak, 216 F.3d at 305.

162. Id. at 307 .

163. Id.

164. Id.

165. The court states that "in the ordinary case, adequate motive arose from the desire to profit from extensive insider sales." See id. at 308. Intentional misconduct "encompasses deliberate illegal behavior, such as securities trading by insiders privy to undisclosed and material information ... or knowing sale of a company's stock at an unwarranted discount." Id. (citation omitted). 
strand ${ }^{166}$ the court observed that its pre-PSLRA cases upheld claims of recklessness where plaintiffs alleged that "defendants knew or, more importantly, should have known that they were misrepresenting material facts related to the corporation." 167 The court seemingly did not recognize that the latter part of this statement sets forth a negligence standard that is far less demanding than the "extreme departure from the standards of ordinary care" that Sundstrand requires. ${ }^{168}$ Novak then compounds the confusion by citing as examples of this standard two cases that did not rely upon it. ${ }^{169}$

Similarly, Novak again uses language suggesting negligence when it states: "Under certain circumstances, we have found allegations of recklessness to be sufficient where plaintiffs alleged facts demonstrating that defendants failed to review or check information that they had a duty to monitor, or ignored obvious signs of fraud." ${ }^{170}$ Moreover, while the court pointed out that it has refused to allow plaintiffs to proceed on the basis of allegations of "fraud by hindsight" and that "there are limits to the scope of liability for failure adequately to monitor the allegedly fraudulent behavior of others," the principles on which its cases rely to set those limits.

If this portion of Novak represented only a recounting of pre-Reform Act authority, one might dismiss as unimportant the court's errors and omissions. But the court perpetuated the possibility that a plaintiff can create a strong inference of scienter by pleading facts that suggest only negligence when it concluded its analysis of section (b)(2) as follows:

When all is said and done, we believe that the enactment of paragraph (b)(2) did not change the basic pleading standard for scienter in this circuit (except by the addition of the words "with particularity"). Accordingly, we hold that the PSLRA adopted our "strong inference" standard: In order to plead scienter, plaintiffs must "state with particularity facts giving rise to a strong inference that the defendant acted with the required state of mind," as required by the language of the Act itself .... [I]n applying this standard, district courts should look to the cases and factors discussed ... above to determine whether plaintiffs have pleaded facts giving rise to the requisite "strong inference." These cases suggest, in brief, that the inference may arise where the complaint sufficiently alleges that the defendants: (1) benefitted in a concrete and personal way from the purported fraud; (2) engaged in deliberately illegal behavior; (3)

166. The court does not attribute that standard to Sunstrand, however. See id.

167. Id. (emphasis added).

168. Id. (citing Rolf v. Blyth, Eastman Dillon \& Co., Inc., 570 F.2d 38, 47 (2d Cir. 1978)).

169. See id. The first, Cosmas v. Hassett, 886 F.2d 8, 12 (2d Cir. 1989), does not discuss scienter on the page Novak cites. When Cosmas does address scienter, it upholds the complaint at least in part because plaintiffs' allegations "do establish a motive." Id. at 13. The second, Goldman v. Belden, 754 F.2d 1059, 1070 (2d Cir. 1985), held that "Rule 9(b) allows intent and knowledge to be alleged generally ...."

170. Novak, 216 F.3d at 308 (emphasis added). While the first part of the quoted statement uses the language of negligence, the second part is ambiguous. Moreover, the first case Novak cites in support of this statement also found that plaintiff adequately alleged defendants had a motive to ignore material facts. $I d$. (citing Rolf, 570 F.2d at 47-48).

171. Novak, 216 F.3d at 309. 
knew facts or had access to information suggesting that their public statements were not accurate; or (4) failed to check information they had a duty to monitor. ${ }^{172}$

Aside from quoting section (b)(1), the only statement in this portion of $\mathrm{No}$ vak that arguably relates to the Basis Requirement is the court's reference to its pre-Reform Act requirement that plaintiffs who contend defendants had access to facts contrary to their public statements "must specifically identify the reports or statements containing this information." However, Novak's discussion is incomplete and therefore potentially confusing in that the court failed to mention that the Second Circuit decision it cited expressly relies on First and Seventh Circuit decisions that require a plaintiff "to "specifically identify the internal reports and public statements underlying their claims, providing names and dates," and to "indicate such matters as "who prepared the projected figures, when they were prepared, how firm the numbers were, or which [company] officers reviewed them." "174 Thus, the court left unclear until it discussed the complaint in the instant case the extent to which it believed section (b)(1) or the words "with particularity" in section (b)(2) incorporate these more rigorous pleading requirements.

b. Analysis of the AnnTaylor complaint. Novak's discussion of the AnnTaylor complaint and of the district court's decision is even more baffling. The court opened this discussion by summarizing plaintiffs' claims that the AnnTaylor defendants "engaged in conscious misstatements with the intent to deceive," and then stated: "There is no doubt that this pleading satisfies the standard for scienter under Hochfelder and the requirement of the PSLRA that plaintiffs state facts with particularity that give rise to a strong inference of the required state of mind." "175 In addition, the court identified as "documentary sources that support the plaintiffs' belief that serious inventory problems existed during the Class Period itself" statements AnnTaylor allegedly made at the end of the first and second quarters of FY 1995, which is after the end of the class period, and data in the January 22, 1996 Weekly Report. ${ }^{176}$

172. Id. at 311 (emphasis added) (internal cross-citations omitted). In the first part of the quoted paragraph, the court may have been referring to the distinction Roskoski notes between its pre-PSLRA "standard" and the "tests" it used to determine whether a plaintiff had met that standard. See Roskoski, supra note 14.

173. Novak, 216 F.3d at 309.

174. See San Leandro Emergency Med. Group Profit Sharing Plan v. Philip Morris Cos., Inc., 75 F.3d 801, 812-13 (2d Cir. 1996) (quoting Serrabian v. Amoskeag Bank Shares, Inc., 24 F.3d 357, 365 (1st Cir. 1994)); Arazie v. Mullane, 2 F.3d 1456, 1467 (7th Cir. 1993) (bracketed material added by court).

175. Novak, 216 F.3d at 312.

176. Id. at 313. An additional indication of the sloppiness of the court's opinion is that the statements the court purports to relate to AnnTaylor's first quarter FY 1995 report in fact represent plaintiffs' unattributed allegations concerning statements an unidentified AnnTaylor employee made to analysts. See Novak Amended Complaint, supra note 121, II 92. Moreover, the court ignored completely both the district court's careful explanation of its reasons for concluding the January 22, 1996 data has almost no probative value and the district court's description of AnnTaylor's business as vulnerable to sharp fluctuations due to changing consumer tastes and purchasing patterns. See Jennifer L. Brady, April Sales Brought Letdown for Stores; Easter Didn't Help, WOMEN's WEAR DAILY, May 5, 
The court's ultimate disposition of plaintiffs' appeal, however, appears flatly inconsistent with the above discussion. The court first declared: "We express no view as to whether the plaintiffs' allegations in this case were sufficiently particularized." 177 It then remanded the case to the district court "with instructions to: (1) allow the plaintiffs to replead in light of our discussion above; and (2) reconsider the particularity of the plaintiffs' pleadings in light of the proper standards." 178 This disposition makes no sense whatsoever if, as the court earlier stated, the complaint "satisfies the standard for scienter under Hochfelder, and the requirement of the PSLRA that plaintiffs state facts with particularity that give rise to a strong inference of the required state of mind," and if plaintiffs have adequately identified "documentary sources that support [their] belief that serious inventory problems existed during the Class Period itself.",179

The best way to make sense of Novak, I believe, is to focus not on these conflicting statements but on the court's conclusion that a plaintiff can comply with the Basis Requirement without naming confidential sources. On this issue, the court held:

[O] ur reading of the PSLRA rejects any notion that confidential sources must be named as a general matter. In our view, notwithstanding the use of the word "all," paragraph (b)(1) does not require that plaintiffs plead with particularity every single fact upon which their beliefs concerning false or misleading statements are based. Rather, plaintiffs need only plead with particularity sufficient facts to support those beliefs. Accordingly, where plaintiffs rely on confidential personal sources but also on other facts, they need not name their sources as long as the latter facts provide an adequate basis for believing that the defendants' statements were false. Moreover, even if personal sources must be identified, there is no requirement that they be named, provided they are described in the complaint with sufficient particularity to support the probability that a person in the position occupied by the source would possess the information alleged. ${ }^{18}$

1995, available in WL 8304420 (reporting that several major women's clothing retailers reported "disheartening" Easter results).

177. Novak, 216 F.3d at 314.

178. Id.

179. An additional flaw in Novak is the conclusion that plaintiffs' allegations concerning statements allegedly made to analysts by the AnnTaylor defendants "were sufficiently detailed to meet the pleading threshold because generally the circumstances of the statements-including dates and participants-were particularized." Id. at 314 (citing Acito v. Imcera Group, Inc., 47 F.3d 47, 51 (2d Cir. 1995)). Acito does not address the issue of when statements allegedly made to analysts can be attributed to an issuer.

Time Warner, the governing authority on this issue, holds that Rule 9(b) requires, "at a minimum, that the plaintiff identify the speaker of the allegedly fraudulent statements." In re Time Warner, Inc. Sec. Lit., 9 F.3d 259, 265 (2d Cir. 1993) (emphasis added). Plaintiffs' amended complaint claims only that two individual defendants spoke to analysts and does not attribute specific, allegedly false or misleading statements to either of them. See Novak Amended Complaint, supra note 121, II II 70-74, 78-81.

180. Novak, 216 F.3d at 313-14 (footnote omitted). In the footnote to this passage, the court astutely observed that

paragraph (b)(1) is strangely drafted. Reading "all” literally would produce illogical results that Congress cannot have intended. Contrary to the clearly expressed purpose of the PSLRA, it would allow complaints to survive dismissal where "all" the facts supporting the plaintiff's information and belief were pled, but those facts were patently insufficient to support that belief. Equally peculiarly, it would require dismissal where the complaint pled facts fully sufficient to support a convincing inference if any known facts were omitted. Our read- 
The court then explained that plaintiffs can satisfy the Basis Requirement "by providing documentary evidence and/or a sufficient general description of the personal sources of the plaintiffs' beliefs." 181 Either kind of information serves the underlying purpose of section (b)(1), which is to ensure that plaintiffs "supply sufficient specific facts to support their allegations." structions on remand are consistent with this explanation. ${ }^{183}$

3. The Issues on Remand. Although Novak is confusing in numerous respects, focusing on the court's holding concerning sources makes it possible to set forth a reasonably coherent interpretation of the court's decision that also is consistent with Silicon Graphics and Greebel. ${ }^{184}$ That interpretation is as follows:

(1) Plaintiffs' can satisfy the scienter requirement established by Hochfelder and by section (b)(2) by claiming that the AnnTaylor defendants made public statements that conflicted with facts they knew or recklessly disregarded. Consequently, the district court cannot dismiss this claim on business judgment grounds. However, it remains an open question whether plaintiffs have satisfied the requirement that they plead all facts on which this claim is based. ${ }^{185}$

(2) Plaintiffs are not required to name their confidential sources, but to satisfy sections (b)(1) and (b)(2), they must describe the documentary and/or personal sources on which they rely; moreover, their allegations, considered in light of the sources on which they are based, must support a strong inference that the AnnTaylor defendants acted with scienter.

\footnotetext{
ing of the provision focuses on whether the facts alleged are sufficient to support a reasonable belief as to the misleading nature of the statement or omission.

Id. at $314 \mathrm{n} .1$.

I previously made a similar argument, to the effect that plaintiffs should be free to decide what information to reveal about their sources and that courts should take account of the basis for plaintiffs' allegations when deciding whether they give rise to a strong inference of scienter. See Weiss \& Moser, supra note 16, at $471 \mathrm{n} .71$. Moreover, the court ignored completely both the district court's careful explanation of its reasons for concluding the January 22, 1996 data has almost no probative value and the district court's description of AnnTaylor's business as vulnerable to sharp fluctuations due to changing consumer tastes and purchasing patterns.

181. Novak, 216 F.3d at 314.

182. $I d$.

183. See supra text accompanying note 175.

184. The interpretation that follows is influenced by the organization of Novak. Several of the court's statements therein make more sense when viewed in relation to the headings of the sections of the opinion in which they appear than if compared to seemingly inconsistent statements in other sections of the opinion.

185. Admittedly, the court stated as part of this holding that plaintiffs' allegations satisfy "the requirement of the PSLRA that plaintiffs state facts with particularity that give rise to a strong inference of the required state of mind." Novak, 216 F.3d at 314. See supra text accompanying note 175. However, this statement conflicts with the court's disposition of plaintiffs' appeal. In addition, this statement is made in the section of the opinion that addresses the substantive standard established by that $\S$ $21 \mathrm{D}(\mathrm{b})(2)$. The best reading of Novak, in my view, is that the court meant this statement to reflect its view that the facts pled by plaintiffs, if credited, would be sufficient to establish recklessness for purposes of section $(b)(2)$.
} 
(3) Now that the court has clarified the meaning of section (b)(1), plaintiffs should be given a chance to replead their claims in light of this clarification.

(4) The district court should then reconsider the complaint, including any additional allegations plaintiffs choose to add, and decide whether the plaintiffs' well-pled allegations give rise to a strong inference that the AnnTaylor defendants deliberately or recklessly misrepresented material facts.

I assume, for purposes of discussion, that the Novak plaintiffs either will not seek to amend their complaint or will amend it only to provide some additional facts describing the source(s) of the allegations in paragraph $35 .^{186}$ If this assumption is correct, the district court, as the above discussion of its opinion suggests, will be free again to dismiss their complaint. More specifically, the district court could reiterate that (1) the January 22, 1996 Weekly Report (and the AnnTaylor defendants' other post-class period statements) provide little support for plaintiffs' claims that AnnTaylor held large amounts of virtually worthless Box \& Hold inventory during the class period, and (2) in any event, plaintiffs have not demonstrated that they have a reasonable factual basis for their assertions concerning the amount and value of AnnTaylor's Box \& Hold inventory during the class period. As concerns paragraph 35, if plaintiffs do not attribute the allegations therein to a person who was in a position to possess the information alleged, the court should refuse to credit those allegations. Even if plaintiffs do attribute those allegations to a credible source, the district court still could reasonably conclude that the facts alleged do not support a strong inference of scienter. ${ }^{187}$

Should the district court reach such a conclusion, and should plaintiffs again appeal, the Second Circuit might take that opportunity to clarify some of the ambiguities in Novak. More important, an appeal of such a decision also would force the Second Circuit to clarify whether it interprets sections (b)(1) and (b)(2) in much the same fashion as do Silicon Graphics and Greebel, or whether

186. This assumption seemed reasonable because the plaintiffs probably either believed that they had already set forth a valid claim or possessed no additional facts to support the allegations they made. In any event, plaintiffs elected not to replead. See Defendants' Memorandum of Law in Support of Motion to Dismiss the Amended Complaint at 1, Novak v. Kasaks, (S.D.N.Y. Nov. 10, 2000) (96 Civ. 3073 (AGS)). Defendants' reply memorandum of law cites to and quotes from the discussion of the issues on remand in a draft of this article posted at <http: //securities.stanford.edu/report $>$ (visited Feb. 4, 2001). See Defendants' Reply Memorandum of Law in Support of Motion to Dismiss the Amended Complaint at 2-3, Novak (No. 96 Civ. 3073).

187. The district court might choose to contrast plaintiffs' claim with the claims upheld in Rothman v. Gregor, 220 F.3d 81 (2d Cir. 2000). The plaintiffs there provided a well-reasoned explanation, grounded in data drawn from the defendant corporations' financial statements, to support their claim that that corporation had recklessly failed to write off royalty payments it had capitalized. See id. at 85 . They also relied on litigation documents that the defendant corporation had filed to support their claim that it had no reasonable expectation of recovering the capitalized royalties. See id. at 86 . In fact, the only puzzling aspect of the court's opinion in Rothman is its statement that "[ $\mathrm{t}]$ he facts of the pending case are not quite as strong as in Novak." Id. at 91. The Rothman plaintiffs' allegations may not have been as strong, but the facts they pled, as described in the court's opinion, seem to me to be considerably stronger. 
the Second Circuit, once generally credited with having the most stringent pleading standard for claims of securities fraud, is now inclined to uphold complaints that the First and Ninth Circuits would dismiss. ${ }^{188}$

\section{B. In re Cell Pathways, Inc. Securities Litigation}

The facts of Cell Pathways are relatively straightforward. Cell Pathways, Inc. ("CPI") is a bio-pharmaceutical company engaged in developing products to prevent and treat cancer. In 1991, CPI discovered a compound called exisulind, subsequently given the trade name "Prevatac," which CPI believed would be useful in the treatment of colonic polyps and in the prevention of colon cancer. Thereafter, CPI began clinical trials of Prevatac to test its efficacy on patients with adenomatous polyposis coli ("APC"), a rare condition in which patients form intestinal polyps that progress to colon cancer if not treated. ${ }^{189}$

In July 1998, the Food and Drug Administration ("FDA") granted CPI "Fast Track" authority to begin a Phase II/III clinical study of Prevatac. ${ }^{190}$ On October 7, 1998, CPI announced that it had filled its enrollment of the clinical study. ${ }^{191}$ A month later, CPI issued a press release predicting that it would complete the Phase II/III clinical study in January 1999 and stating that if the results were favorable, it would seek FDA approval during the first half of 1999 to begin marketing Prevatac to patients with APC. ${ }^{192}$

On February 1, 1999, CPI announced that the clinical trial had not produced "a statistically significant clinical response." 193 In an interview with Bloomberg Forum the following day, plaintiffs allege, CPI's CEO "noted the possibility

188. Several recent decisions by district courts in the Second Circuit dismiss complaints because plaintiffs failed to detail the basis for their allegations. See Feasby v. Industri-Matemik Int'l Corp., No. 99 CIV.8761(HB), 2000 WL 977673, at *4-6 (S.D.N.Y. July 17, 2000); Sabratek Corp. v. Keyser, No. 99 CIV. 8589(HB), 2000 WL 423529, at*3-4 (S.D.N.Y. Apr. 19, 2000); Ruskin v. TIG Holdings, Inc., No. 98 Civ. 1068 LLS, 1999 WL 756466, at *4 (S.D.N.Y. Sept. 24, 1999). But see In re MCI Worldcom, Inc. Sec. Litig., 93 F. Supp. 2d 276, 283 (E.D.N.Y. 2000) (applying a more lax scienter standard to a misrepresentation of marginal materiality). Cf. Ruskin v. TIG Holdings, Inc., No. 98Civ.1068(LLS), 2000 WL 1154278 , at $* 4$ (S.D.N.Y. Aug. 14, 2000) (refusing to dismiss amended complaint identifying as basis for plaintiffs' allegations internal memoranda written by senior officers of defendant corporation).

After Silicon Graphics was handed down, district courts in the Ninth Circuit have consistently dismissed complaints when plaintiffs have not specified the basis for factual claims made on information and belief. Compare In re Secure Computing Corp. Sec. Litig., 120 F. Supp. 2d 810, 821 (N.D. Cal. 2000); In re FVC.Com Sec. Litig., No. 99-1815 CRB, 2000 WL 1202065, at*7 (N.D. Cal. Feb. 14, 2000); Dalarne Partners, Ltd. v. Synch Research, Inc., 103 F. Supp. 2d 1209, 1214 (C.D. Cal. 2000); In re CBT Group PLC Sec. Litig., No. C-98-21014 RMW, 1999 WL 1249287, at *4 (N.D. Cal. July 21, 1999) (dismissing complaints) with Imperial Credit Indus., Inc. Sec. Litig., Fed. Sec. L. Rep. (CCH) II 91, 024 (C.D. Cal. Feb. 23, 2000) (upholding complaint based on identified e-mails and internal reports). See also In re Segue Software, Inc. Sec. Litig., 106 F. Supp. 2d 161 (D. Mass. 2000) (post-Greebel decision dismissing complaint quite similar to Novak Amended Complaint).

189. See In re Cell Pathways, No. 99-725, 2000 WL 805221, at *1 (E.D. Pa. June 20, 2000).

190. See Consolidated Amended Complaint II 45, In re Cell Pathways, Inc. Sec. Litig., (E.D. Pa. June 28, 1999) (No. 99-752) [hereinafter CPI Complaint]. Phase III is the final stage of clinical study of a new pharmaceutical product. See id. II II 40-42.

191. See id. II 48.

192. See id. II 49.

193. Id. II 57. This announcement led to a sharp decline in the price of CPI stock. See id. II 58. However, plaintiffs make no claim that CPI ever misrepresented the potential of Prevatac. 
that design flaws, particularly in patient selection, could have accounted for the drug's apparent lack of statistically significant efficacy, and indicated his intention to review the findings of the trial." ${ }^{194}$ CPI discussed the results of that review on June 15-16, 1999, disclosing that (1) only thirty-four of the sixty-five patients who had completed the clinical trial in fact met its selection criteria; (2) unqualified patients had been admitted to the study by referring physicians with "little experience" with APC; (3) Prevatac had demonstrated statistically significant benefits for the subgroup of eligible patients; and (4) because of the small size of the subgroup of eligible patients, the FDA would require further testing. ${ }^{195}$

Plaintiffs brought suit on behalf of all persons who purchased CPI stock between October 8, 1998, and February 2, 1999, inclusive. ${ }^{196}$ Plaintiffs' central claim, which they based entirely on the statements by defendants described above ${ }^{197}$ was that CPI acted recklessly in designing the Phase II/III clinical trial as it did:

What is clear from the disclosures made by defendants in June, 1999, is that in selecting physicians to identify patients who would fall within the target population defendants knowingly or recklessly disregarded, in their rush to complete the Fast Track approval process, the great difficulty of identifying the target population in light of the rare nature of APC and most physicians' lack of familiarity with its symptoms. Notwithstanding that knowledge, defendants knowingly or recklessly failed to take steps to ensure that the physicians identifying patients for the study had the special experience, knowledge, qualifications, and expertise to perform their task properly. ${ }^{198}$

Plaintiffs further alleged that CPI's public statements about the Phase II/III clinical trial were materially false and misleading because they did not describe the alleged flaws in the design of that clinical trial and were made with scienter "because at the time of their publications, defendants knew, or recklessly disregarded, that [CPI] had failed to design [properly that] clinical trial." ${ }^{199}$ Plaintiffs also asserted that "defendants were motivated to conceal the true nature of CPI's clinical trials in order to maintain the market's perception that CPI would be the first company with an FDA-approved ... novel investigational drug ... for APC," but made no claim that CPI or any of its officers or directors sold CPI stock during the class period. ${ }^{200}$

The facts alleged clearly do not support plaintiffs' conclusory allegation that defendants acted "knowingly or recklessly." Those facts suggest, at most, that CPI may have been negligent in designing the Phase II/III study or in recruiting physicians to participate in it. Moreover, other facts alleged by plaintiffs make

194. Id. II 59.

195. Id. III 60-62.

196. See id. II 2.

197. Plaintiffs mention no other sources in their brief in opposition to defendants' motion to dismiss. See Plaintiffs' Memorandum of Law in Opposition to Defendants' Motion to Dismiss at 12-14,

30-32, In re Cell Pathways, Inc. Sec. Litig. (E.D. Pa. Jan. 12, 1999) (No. 99-752).

198. CPI Complaint, supra note 190, II 63.

199. Id. If 65(e).

200. Id. II 68. 
clear that designing the clinical trial badly would not have served CPI's interests. Prevatac was a unique drug that CPI believed would effectively treat a rare condition-APC. Plaintiffs' description of CPI, its business, and Prevatac all suggest CPI had no reason to believe Prevatac would produce beneficial results in patients who did not suffer from APC. ${ }^{201}$ Consequently, including patients who did not have APC in the clinical trial would jeopardize, not enhance, the prospect that the trial would produce statistically significant positive results. The facts alleged support neither plaintiffs' claim that defendants acted recklessly when they designed the Phase II/III clinical trial nor their claim that CPI acted with scienter when it made public statements about the clinical trial that did not disclose the problems CPI subsequently discovered in its design.

The district court ignored these glaring weaknesses when it denied both defendants' motion to dismiss and defendants' subsequent motion seeking reconsideration or certification of the case for interlocutory review. ${ }^{202}$ Only after defendants filed a petition seeking a writ of mandamus did the district court issue an opinion explaining its decisions. ${ }^{203}$ The court recognized that the Reform Act requires plaintiffs to meet more demanding pleading standards but then flouted those requirements. Its discussion of the Basis Requirement may best reflect its attitude. The court acknowledged that section (b)(1) requires plaintiffs to plead with particularity all facts on which their claims are based but then indicated its intent to dilute that requirement by quoting the following statements made in pre-Reform Act cases:

Plaintiffs need not, however, plead the "date, place or time" of the fraud, so long as they use an "alternative means of injecting precision and some measure of substantiation into their allegations of fraud" .... [T]he Third Circuit has cautioned that courts should "apply the rule with some flexibility and should not require plaintiffs to plead issues that may have been concealed by the defendants."

The court's central finding - that plaintiffs "have adequately alleged that CPI acted with deliberate recklessness in pushing forward with a clinical trial which they knew was flawed"- cannot be squared with section (b)(1) because no facts pled by plaintiffs demonstrate that CPI was aware of the flaws in the clinical trial at the time it made the challenged statements. ${ }^{205}$ More generally, the court erred when it credited certain allegations plaintiffs made without requiring plaintiffs to plead the facts on which they were based. ${ }^{206}$

201. See id. III 29-32.

202. See In re Cell Pathways, No. 99-725, 2000 WL 805221, at*1 (E.D. Pa. June 20, 2000).

203. See id.

204. Id. at $* 5$ (internal citations omitted).

205. $I d$. at $* 8$.

206. For example, the court said that paragraph 62 of the complaint supports plaintiffs' assertion that

in a conference call to stock market analysts on June 16, 1999, [a CPI official] stated that the medical records needed to identify persons who would fall within the patient target population, those forming ten to forty polyps per year, were not obtained and analyzed until after the Phase III trial was concluded.

$I d$. at $* 4$ n.2. But paragraph 62 contains only one identified statement by a CPI official, to the effect that the "trial data revealed a higher degree of variability in polyp formation by [the patients included 
A second problem is that the court apparently did not appreciate the limited nature of some of plaintiffs' claims. For example, facts pled by plaintiffs arguably provide support for their claim, on which the court heavily relied, that CPI officials "had knowledge of the potential flaws in the enrollment process" at the time CPI made the challenged statements about the Phase II/III clinical trial. ${ }^{207}$ But plaintiffs' use of the phrase "knowledge of the potential flaws" makes clear that they are asserting no more than that senior CPI officials presumably were familiar with the protocols governing clinical studies and therefore should have been aware of potential problems with the enrollment process they employed. Such allegations fall far short of the claim the court said plaintiffs had adequately alleged: that, as of February 1, 1999, CPI knew or recklessly disregarded the fact that there were flaws in the enrollment process and knew or recklessly disregarded that those flaws were highly likely to jeopardize the statistical integrity of the Phase II/III clinical trial. This deficit is not remedied by the court's finding that plaintiffs identified "the sources for their beliefs that the trial was flawed." 208 That plaintiffs believe the trial was flawed is unimportant; the relevant question is whether plaintiffs alleged facts that suggest defendants knew or recklessly disregarded the fact that the trial was flawed at the time they made the challenged statements. ${ }^{209}$

These problems are serious, but the most substantial deficit in the court's decision is the absence of any reasoned explanation of how-even if one assumes that plaintiffs did allege some facts that suggest defendants' actions in designing the clinical trial may have been reckless - defendants' alleged failure to take note of and to disclose the potential problems with the clinical trial conceivably could be viewed as involving "an extreme departure from the standards of ordinary care ... which presents a danger of misleading buyers or sellers that [was] either known to the defendant[s] or [was] so obvious that the[y] must have been aware of it." ${ }^{210}$ In other words, even if the Cell Pathways complaint somehow could be deemed to satisfy the requirements of section (b)(1), there is no way in which the court reasonably could find that it gives rise to a

in the study] than had previously been thought by experts in this disease." CPI Complaint, supra note 190, at II 62. Note that the official's statement is to the effect that CPI was surprised by the variability in polyp formation revealed by the trial data, not that CPI did not obtain patient records until after the Phase III trial was concluded. If the court was relying on the added assertion in paragraph 62 that a CPI executive "would later suggest that other factors, like an insufficient 'degree of scrutiny' of patient medical records had led to inclusion of enough ineligible patients to cripple the trial," the court should have noticed that plaintiffs did not identify any documentary or other source for that assertion. CPI Complaint, supra note 190, at II 62. Thus, the assertion should not have been credited.

207. Cell Pathways, 2000 WL 805221, at *7 (emphasis added).

208. $I d$. at $* 9$ (emphasis added).

209. Another problem with plaintiffs' claim is that the defendants probably did not have a duty to disclose "potential problems" with the clinical study until they knew that those problems would, in fact, jeopardize the integrity of the study. See In re Carter-Wallace Inc. Sec. Litig., 220 F.3d 36, 40 (2d Cir. 2000) (holding that "statements 'did not become materially misleading until Carter-Wallace had information that Felbatol had caused a statistically significant number of aplastic-anemia deaths and therefore had reason to believe that the commercial viability of Felbatol was threatened"').

210. See In re Advanta Corp., 180 F.3d 525, 535 (3d Cir. 1999) (quoting McLean v. Alexander, 599 F.2d 1190, 1197 (3d Cir. 1979)) (holding that this is the governing standard of recklessness). 
strong inference that defendants acted with the requisite degree of recklessness when they issued the statements that plaintiffs claim were materially false or misleading. ${ }^{211}$

One might dismiss Cell Pathways as simply a bad district court decision had the court not noted defendants' petition for a writ of mandamus. That gives Cell Pathways added importance. A decision by the Third Circuit to grant the requested writ would have signaled that court's determination to require plaintiffs to comply with the Reform Act's stringent pleading requirements. ${ }^{212}$ The Third Circuit's decision not to hear defendants' petition ${ }^{213}$ sends a more ambiguous message. District courts could read it as either affirming federal appellate courts' traditional reluctance to review district court denials of motions to dismiss or as an indication that the Third Circuit is prepared to tolerate district court decisions that flout the requirements of the Reform Act. ${ }^{214}$

The Third Circuit was the first appellate court to consider the Reform Act's pleading standards at length. The plaintiffs' allegations in Advanta, the case in which that court did so, were extremely weak, ${ }^{215}$ which makes it difficult to determine to what extent, if any, the Third Circuit's views of the Reform Act differ from the interpretations set forth in Silicon Graphics and Greebel.

Advanta concludes that section (b)(2) "was intended to modify procedural requirements while leaving substantive law undisturbed." 216 As a matter of substantive law, Advanta holds, "it remains sufficient for plaintiffs to plead scienter by alleging facts 'establishing a motive and an opportunity to commit fraud, or by setting forth facts that constitute circumstantial evidence of either reckless or conscious behavior." "'17 But, the court continued:

Motive and opportunity, like all other allegations of scienter (intentional, conscious, or reckless behavior), must now be supported by facts stated "with particularity" and must give rise to a "strong inference" of scienter. These heightened pleading requirements address the previous ease of alleging motive and opportunity on the part of corporate officers to commit securities fraud .... After the Reform Act, catch-all allega-

211. See id. at 540 (noting that the allegation that defendants disregarded negative trends, "even if true, would not demonstrate [the] 'extreme departure' from the standards of ordinary care" that is necessary to show scienter).

212. As of September 1, 2000, defendants' petition had been pending before a motions panel of the Third Circuit for more than two months.

213. On September 29, 2000, the Third Circuit issued an order denying the petition without opinion. See In re Cell Pathways, Inc. Sec. Litig., No. 00-1643 (3d Cir. Sept. 29, 2000).

214. The Third Circuit might well have been concerned that, had it issued the requested writ of mandamus, it would be inundated with requests for such writs from defendants whose motions to dismiss securities fraud complaints were denied. On the other hand, the Third Circuit could have limited that risk by explaining that it was reviewing the district court's decision in Cell Pathways only because it provided a unique opportunity to furnish district courts with guidance on important pleading issues that the appellate court had not previously addressed. See infra text accompanying notes 215-220.

215. The court held that plaintiffs' factual allegations did not support plaintiffs' claim that defendants' challenged statements were either false or misleading. See Advanta, 180 F.3d at 537-39. As concerned scienter, the court found that plaintiffs offered only "conclusory assertions that the defendants acted 'knowingly,' [and] blanket statements that defendants must have been aware of the impending losses by virtue of their positions within the company." Id. at 539 (citation omitted).

216. Id. at 534 .

217. Id. at 534-35 (quoting Weiner v. Quaker Oats Co., 129 F.3d 310, 318 n.8 (3d Cir.1997)). 
tions that defendants stood to benefit from wrongdoing and had the opportunity to implement a fraudulent scheme are no longer sufficient, because they do not state facts with particularity or give rise to a strong inference of scienter. ${ }^{218}$

On the recklessness issue, the court reiterated the Third Circuit's "previous holding that it remains a sufficient basis for liability," as well as the relevant definition of recklessness set forth in Sunstrand. ${ }^{219}$

These statements suggest that the Third Circuit intends to interpret the Reform Act in much the same fashion as have the First, Sixth, Ninth, and Eleventh Circuits, except insofar as Advanta's discussion of motive and opportunity may suggest a slightly lower pleading threshold than those courts have adopted. Plaintiffs in Cell Pathways did not allege, and the district court did not find, motive and opportunity, so a decision on the merits by the Third Circuit in Cell Pathways would not have clarified whether it takes a different view of those factors than do the other circuits. But Cell Pathways could have provided the Third Circuit with an excellent vehicle to elaborate on the need for plaintiffs to satisfy section (b)(1)'s Basis Requirement, which Advanta noted but did not discuss. ${ }^{220}$

VI

\section{CONCLUSION}

This article applauds the manner in which the First and Ninth Circuits have interpreted the Reform Act's pleading requirements and urges other courts to adopt similarly stringent interpretations of sections (b)(1) and (b)(2). It takes that position because plaintiffs' attorneys, prior to the passage of the Reform Act, regularly used "the litigation process as a device for extracting undeserved settlements as the price of avoiding the extensive discovery costs that frequently ensue once a complaint survives dismissal."221 Requiring plaintiffs to meet more stringent pleading standards is a viable-and perhaps the best—strategy for dealing with that problem.

Some surely will argue that the Reform Act, as interpreted in Silicon Graphics and Greebel, shortchanges society's "interest in deterring fraud in the securities markets and remedying it when it occurs,"222 which can be protected only by providing investors who believe they are the victims of fraud with an opportunity to conduct discovery of those they suspect of having perpetrated the fraud. ${ }^{223}$ Viewed in a void, this argument no doubt has merit. Cases surely

218. Id. at 535 (citation omitted and emphasis added).

219. Id.

220. The court assumed, arguendo, that plaintiffs' allegations were true and held that "[e]ven if the positive portrayals were materially misleading, we believe the complaint suffers a more fundamental defect in that it fails to satisfy the Reform Act's requirements for pleading scienter." Id. at 539.

221. In re Time Warner, Inc. Sec. Litig., 9 F.3d 259, 263 (2d Cir. 1993); see also Elkind, supra note 31.

222. Id.

223. See supra text accompanying note 1 . 
will arise in which, as a consequence of the Reform Act's pleading standards, frauds will go unremedied. ${ }^{224}$

But that is beside the point. As Judge Newman recognized years ago, any pleading standard, no matter how drafted, will result in some frauds going unremedied and some undeserved settlements being extracted. ${ }^{225}$ The relevant inquiry, from a policy point of view, ${ }^{226}$ is whether the Reform Act, as interpreted in Silicon Graphics and Greebel, gets the balance right.

The short answer is that it is far too early to tell. Little more than a year has passed since the first group of appellate decisions interpreting sections (b)(1) and (b)(2) were handed down. Prior to that time, district courts had adopted a variety of different interpretations of the Basis and Strong Inference Requirements. Many plaintiffs' attorneys no doubt followed what they viewed as an economically rational strategy: Where publicly available information suggested a fraud may have occurred, they incurred as little in the way of investigation costs as possible in the hope that the court would interpret the Reform Act in a fashion that would allow them to use discovery to search for evidence of fraud. ${ }^{227}$ Moreover, uncertainty remains as to whether a number of circuits-including the Second and the Third-will interpret the Basis and Strong Inference Requirements as do Silicon Graphics and Greebel.

As a consequence, it probably will be many years before researchers have enough data to determine with any degree of confidence whether the costs generated by the Reform Act, measured in terms of unremedied frauds, outweigh the benefits. One possibility is that if courts uniformly begin to demand more of plaintiffs, plaintiffs' attorneys will become more skilled at ferreting out evidence of fraud or explaining how available facts support a strong inference that a fraud occurred. ${ }^{228}$ Nonetheless, situations surely will arise where the facts available to potential plaintiffs will stimulate strong suspicions that a fraud has occurred but will not support a complaint that meets the requirements of sections (b)(1) and (b)(2). ${ }^{229}$ I have argued elsewhere that courts could allow a

224. Cf. In re Green Tree Fin. Corp. Stock Litig., 61 F. Supp. 2 d 860 (D. Minn. 1999); Weiss \& Moser, supra note 16.

225. See supra text accompanying note 1; see also Lynn A. Stout, Type I Error, Type II Error, and the Private Securities Litigation Reform Act, 38 ARIZ. L. REV. 711 (1996).

226. From what might be termed a legal point of view, it seems clear that the language and, to the extent it is relevant, the legislative history of sections (b)(1) and (b)(2) provide substantial support for the manner in which Silicon Graphics, Greebel, Comshare and Avado interpret those provisions. And, "[i]f Congress erred, ... it is for that body, and not [the courts], to correct its mistake." Reves v. Ernst \& Young, 494 U.S. 56, 63 n.2 (1990).

227. In Cell Pathways, for example, after the court denied defendants' motion to dismiss, plaintiffs made 92 document requests that, taken together, called for "the production of virtually every document in Defendants' possession." CPI Petition, supra note 190, at 8.

228. See, e.g., Rothman v. Gregor, 220 F.3d 81 (2d Cir. 2000), discussed supra note 187.

229. But see Weiss \& Moser, supra note 16, at 460, noting that three important categories of cases are largely unaffected by the Reform Act's pleading requirements:

(i) cases where the "bad news" statement that precipitates a claim also makes it clear that some earlier statement made by defendants was false or misleading, as is often the case when a corporation restates its earnings for some earlier period; (ii) cases where, in connection with the "bad news" statement, some third party discloses information that indicates that one or 
plaintiff to rely on the "undue prejudice" exception to the Reform Act's discovery stay to take limited discovery, provided she is

able to show that defendants control information critical to her claim and also [can] (i) plead particularized facts sufficient to make out most elements of a claim of securities fraud; (ii) show that she has made a diligent effort to obtain the remaining information necessary to flesh out her claim; and (iii) convince the court that she has reasonable grounds to believe that particularized discovery will produce that information. ${ }^{230}$

In 1999, the Ninth Circuit issued a writ of mandamus reversing a district court decision allowing a plaintiff to take limited discovery where the district court found she had met somewhat similar conditions. ${ }^{231}$ The appellate court reasoned that to allow a plaintiff to take discovery in such circumstances would contravene Congress's clear intent "that complaints in these securities actions should stand or fall based on the actual knowledge of the plaintiffs rather than information produced by the defendants after the action has been filed." ${ }^{232}$

The Ninth Circuit's reasoning seems flawed. Congress expressly provided that a plaintiff should be allowed to conduct discovery where she could show "undue prejudice" ${ }^{133}$ and never discussed what was meant by that term. ${ }^{234}$ In addition, the case on which the Ninth Circuit relied dealt with quite a different issue: whether, in a district whose rules provide for "disclosure," plaintiffs in cases involving allegations of securities fraud routinely should be allowed to compel defendants to make disclosure before the court ruled on defendants' motion to dismiss. ${ }^{235}$

The Ninth Circuit, however, may well have been influenced by more pragmatic concerns. In proposing the above interpretation of the undue prejudice exception to the discovery stay, I recognized the danger that if courts were to begin to allow discovery if the specified conditions were met, every plaintiff who found she could not develop sufficient facts to allow her to draft a complaint that would survive a motion to dismiss would be tempted to claim "undue prejudice."236 Given the persistence with which some plaintiffs' attorneys have continued to attempt to base claims of securities fraud on "boilerplate allegations, ${ }^{237}$ the court might well have feared that a decision that allowed plaintiffs,

more of a corporation's earlier statements were false or misleading; and (iii) cases where the temporal proximity between the "bad news" statement and the "earlier, cheerier" statement, combined with the magnitude of the changes between the two, strongly suggests that a corporation was aware of the bad news at the time it made the earlier statement.

(footnotes omitted.)

230. Weiss \& Moser, supra note 16 , at 506.

231. See SG Cowen Sec. Corp. v. United States Dist. Court, 189 F.3d 909 (9th Cir. 1999). But cf. In re Flir Sys., Inc. Sec. Litig., No. Civ. 00-360-HA, 2000 WL 33201904 (D. Ore. Dec. 13, 2000) (allowing plaintiff to depose third party who defendant had threatened to sue if he volunteered information to plaintiff).

232. Id. at 912 (quoting Medhekar v. United States Dist. Court, 99 F.3d 325, 328 (9th Cir.1996)).

233. Securities Exchange Act of 1934, § 21D(b)(3)(B), 15 U.S.C. $§ 78 u-4(b)(3)(B)$ (Supp. IV 1998).

234. See Weiss \& Moser, supra note 16, at 501.

235. See Medhekar, 99 F.3d at 326.

236. See Weiss \& Moser, supra note 16, at 506.

237. See sources cited supra note 55. 
even in sharply defined circumstances, to plead "undue prejudice" would result in such a claim being made in virtually every case in which a district court granted defendants' motion to dismiss.

Regardless, with or without the possibility of limited discovery, it will be many years before anyone can demonstrate with any degree of certainty whether or not the Reform Act's pleading provisions serve society's interests better than did the notice pleading regime that preceded them. 


\section{APPENDIX}

As noted in the text, an attorney experienced in prosecuting class actions alleging securities fraud will appreciate that plaintiffs must show not only that they incurred losses, but that (1) some earlier statement or statements made by or on behalf of the potential defendant ("Defendant") were materially false or misleading at the time they were made-falsity - (2) that Defendant or one or more of its senior officials issued the earlier statements with an intent to deceive or defraud-scienter-and (3) that the earlier statements inflated the market price of Defendant's stock and thus contributed to or caused the losses investors have incurred-causation. ${ }^{\mathrm{A}}$

To satisfy the falsity requirement, plaintiffs must specify why Defendant's "earlier, cheerier" statements were false or misleading at the time they were made. Under the Reform Act, plaintiffs also must plead with particularity facts sufficient to give rise to a strong inference that the "earlier, cheerier" statements were issued with an intent to deceive or defraud.

In most such situations, plaintiffs' attorney will not know precisely what information, if any, relating to the subsequently announced bad news was available to Defendant and its senior officers at the time the earlier statements were made, nor will it be easy for plaintiffs' attorney to ascertain whether Defendant or its senior officers were aware of or deliberately ignored any such information. However, plaintiffs' attorney usually will find it easy to identify some earlier statements by Defendant or its senior officers that discuss the subject to which the unanticipated "bad news" relates. Plaintiffs' attorneys then can use the facts disclosed in Defendant's "bad news" statement and facts available from other public sources to draft allegations that reflect no more than speculation or conjecture but that appear to set forth particularized facts, which, if credited, virtually compel the conclusion that Defendant knew its "earlier cheerier" statements were materially false or misleading at the time they were made.

The following examples illustrate this practice.

\section{A. Declining Sales ${ }^{\mathrm{A} 2}$}

Acme Corporation, a manufacturer of electronic widgets, has reported quarter-to-quarter increases in sales and profits for thirty consecutive quarters. Following the third quarter of the current year, Acme announces unexpected bad news: Its sales for the quarter were flat, as compared to the previous quar-

A1. If Defendant corporation's stock is traded in an efficient market, such as the New York Stock Exchange or NASDAQ, a court will presume that a materially false or misleading public statement made by or on behalf of Defendant corporation influenced the price of its stock. See Basic, Inc. v. Levinson, 485 U.S. 224 (1988).

A2. This illustration is based in large part on the court's discussion of plaintiff's complaint in Cooper v. Pickett, 137 F.3d 616, 626 (9th Cir. 1998). 
ter, and its profits declined. ${ }^{\mathrm{A} 3}$ The price of Acme's stock drops by more than fifty percent following this announcement. Plaintiff's attorney L does a quick analysis of Acme's business and history and concludes that there are reasonable grounds to believe that Acme's sales and earnings began to flatten out prior to the third quarter. L also estimates how much Acme's sales and earnings would have been in each of the prior two quarters had its decline followed what L considers to be a more normal trajectory. Finally, L ascertains from Acme's filings with the SEC and other public sources that Acme's four largest customers are WW, XX, YY, and ZZ.

With this information in hand, L (after having been retained by one or more recent purchasers of Acme stock) files a class action, on behalf of all persons who purchased Acme stock subsequent to Acme's announcement of its earnings for the first quarter, alleging that Acme's management has been aware for at least six months of a decline in Acme's sales and that, in an effort to mislead investors, Acme knowingly issued financial statements for the first and second quarters that included materially inflated statements of Acme's revenues and income. L supports these claims by including in the complaint the following "particularized" allegations:

In each of the first and second quarters, Acme deliberately shipped excessive amounts of widgets to its largest customers. In many instances, Acme promised these customers that they would not have to pay for the widgets unless and until they re-sold them. In other instances, Acme actually shipped merchandise that had not been ordered by the customer. These customers included WW, XX, YY, and ZZ.

Generally accepted accounting principles required Acme to defer revenue recognition of income with respect to these shipments until payment was received, but Acme instead reported these shipments as sales in order to overstate its revenues and net income. This resulted in Acme overstating its revenues, net income, and earnings per share for the first and second quarters in material dollar amounts that $\mathrm{L}$ derives by estimating, in consultation with an expert accountant, what Acme's revenues, net income, and earnings per share would have been had Acme's sales declined in accord with L's estimate.

\section{B. Failed Expansion ${ }^{\mathrm{A} 4}$}

Baker Corporation announces on April 2 of the current year that its earnings declined in the first quarter from first quarter earnings for the previous year-the first year-to-year decline in Baker's history. Baker also states that

A3. A similar scenario arises where a company announces that its sales failed to increase as rapidly as the market had anticipated.

A4. This illustration is based in large part on the court's discussion of plaintiff's complaint in Fecht v. The Price Co., 70 F.3d 1078, 1083 nn.5, 6 (9th Cir. 1995). 
the decline was due, in large part, to disappointing sales and resultant losses at several stores that Baker recently had opened. Following this announcement, the price of Baker stock declines by thirty percent. Attorney L ascertains that during the past nine months Baker had made several positive statements about its expansion program. The most recent of these was issued on January 16 when a Baker press release stated that Baker's expansion program "was going well" and that most of Baker's recently opened stores were "quite successful." $\mathrm{L}$ also ascertains from Baker's most recent Form 10-K that during the previous eighteen months, Baker opened new stores in WW, XX, YY and ZZ. Finally, in early June, L learns from a Baker press release that Baker has decided to close its new stores in YY and ZZ.

L concludes that Baker must have been aware of problems at some of its new stores before it issued the January 16 statement, given that problems probably were evident at the end of the fourth quarter, in which Baker's stores typically generate more than fifty percent of their sales, and that Baker probably was aware of problems at some of those stores by July 15 of the previous year, when Baker also issued positive comments about its expansion program. Based on these beliefs, L (after having been retained by an investor who purchased Baker stock between July 15 of the previous year and April 2) files a class action, on behalf of all persons who purchased Baker stock between July 15 and April 2, alleging that as of or prior to July 15, Baker's management was aware of developing problems at its four new stores and that, in an effort to mislead investors, Baker deliberately issued materially false and misleading statements concerning its expansion program. To support this claim, L includes in the complaint an allegation that five senior mangers of Baker, all of whom $\mathrm{L}$ names as defendants, received weekly, monthly, and quarterly reports that included information on the sales and profitability of each of Baker's stores and the following "particularized" allegations:

During the period beginning eighteen months before April 2 and ending the previous April 2, Baker opened new stores in WW, XX, YY, and ZZ. Initial sales volumes of these newly opened stores were below levels usually experienced by Baker at newly opened stores and below levels necessary for the stores to achieve profitable operations. Recent store openings in WW, XX, YY, and ZZ were proceeding poorly and most of these units were losing money. At least for the near term, Baker faced a major threat of eroding profits and declining margins because of the size of the losses being suffered at Baker's newly opened stores, especially in YY and ZZ. Baker's new stores in YY and ZZ were performing very poorly and suffering significant losses that were adversely affecting Price Company's overall results.

Prior to the beginning of the class period and throughout the class period, the defendant senior managers of Baker received weekly, monthly, and quarterly reports advising each of them of the disap- 
pointing sales and losses incurred at the stores in WW, XX, YY, and ZZ. Prior to January 16, those managers also knew, or recklessly disregarded the fact, that the losses Baker was incurring at its stores in YY and $\mathrm{ZZ}$ were so large that it was apparent Baker would have to close those stores.

\section{Accounting Irregularities ${ }^{\mathrm{A} 5}$}

Charlie Corporation licenses software. For a number of years, it has reported steadily rising revenues and earnings. On August 6, Charlie issues a press release disclosing that it is delaying release of its results for the year ending June 30 pending completion of its year-end audit. Charlie further discloses that it has expanded its audit to include a detailed review of orders generated by its United Kingdom subsidiary in the United Kingdom and other foreign countries after discovering letters setting forth conditions to approximately $\$ 4$ million in orders of which Charlie was not aware when it recognized revenues from those orders. Following this disclosure, the price of Charlie stock drops from $\$ 18.50$ to $\$ 11.875$.

One month later, Charlie issues its Form 10-K for the fiscal year, in which it discloses that in the course of the year-end audit, it discovered side letters issued by personnel at Charlie's U.K. subsidiary that set "forth conditions to certain foreign orders in violation of the Company's revenue recognition policies." ${ }^{\mathrm{A} 6}$ These letters related to approximately $\$ 6.9$ million in revenues that Charlie improperly recognized, some of which had been recognized in "prior quarters and years." ${ }^{\mathrm{A} 7}$ The Form 10-K also reports that Charlie's fourth quarter revenue, as reported, was about seven percent below that in the previous year, that Charlie's total revenue for the year increased $9.8 \%$, but that Charlie incurred a pre-tax loss of $\$ 13.7$ million for the year, as compared to a pre-tax profit of $\$ 2.1$ million in the prior year. The Form $10-\mathrm{K}$ further states that Charlie was not restating any prior period results, that Charlie found no violations of its revenue recognition policies in connection with U.S orders, and that Charlie has taken "corrective actions... including management changes, personnel terminations and other disciplinary actions and the establishment of new orders procedures." ${ }^{\mathrm{A} 8}$

Attorney L checks Charlie's filings with the SEC and ascertains that Charlie's chief executive officer sold about $\$ 2.5$ million in Charlie stock during the

A5. This illustration is based in part on plaintiffs' Consolidated Amended Class Action Complaint, Dec. 13, 1996, In re Comshare Inc. Sec. Litig., 1997 U.S. Dist. LEXIS 17262 (E.D. Mich. Sept. 18, 1997) (No. 96-73711) and in part on allegations that plaintiffs asserted they would make if they were granted leave to amend that complaint. See Appellants Petition for Rehearing and Rehearing en Banc, In re Comshare Inc. Sec. Litig., 183 F.3d 542 (6th Cir. 1999) (No. 97-2098). That complaint and those allegations were the focus of the court's decision in Comshare.

A6. Consolidated Amended Class Action Complaint, at 86, Dec. 13, 1996, In re Comshare Inc. Sec. Litig., 1997 U.S. Dist. LEXIS 17262 (E.D. Mich. Sept. 18, 1997) (No. 96-73711).

A7. Id.

A8. Id. 
year prior to the August 6 announcement and that three other Charlie executives sold a total of about $\$ 1.8$ million in Charlie stock during the same period. The last of these sales, however, occurred almost two months before the August 6 announcement. L also meets with an accounting expert and is advised that when contingent sales occur, a company's accounts receivable usually build-up somewhat more rapidly than do its revenues because no payments will be received with respect to the contingent sales until the contingencies have been satisfied. A variety of financial reports usually will reflect this buildup in accounts receivable.

Based on this information, L (after having been retained by an investor who recently purchased Charlie stock) files a class action on behalf of all persons who purchased Charlie stock between the date Charlie issued its financial results for the prior year and August 6. The complaint names as defendants Charlie and the four executives who sold Charlie stock, details the sales of Charlie stock by those defendants, and alleges that Charlie and those defendants were parties to a scheme to falsify Charlie's revenues and profits during the class period. The complaint further alleges:

Throughout the Class Period, defendants entered into and were parties to a scheme falsely to inflate Charlie's reported annual and quarterly revenues and profits by agreeing that certain conditions would be included in side letters with certain customers who had ordered software licenses from Charlie. In furtherance of this scheme, Defendants reported the revenues, and hence the profits, from these licenses despite that fact that, because of the conditions in the side letters, recognizing those revenues was a violation of both Charlie's revenue recognition policies and Generally Accepted Accounting Principles.

Charlie and the individual defendants were aware of the side letters or were recklessly indifferent to "red flags" indicating that the side letters had been issued and that revenues from substantial amounts of contingent sales had improperly been recognized. In particular:

(A) Charlie and the individual defendants received monthly and quarterly reports that disclosed increasing accounts receivable resulting from the phony sales over time.

(B) Charlie and the individual defendants received and monitored payment schedules from Charlie's accounts receivable so that they could estimate the amount and timing of cash collections and also received accounts receivable aging schedules to assess the necessary level of reserves for uncollectible accounts. These reports disclosed that the accounts receivable from the phony sales were delinquent for extended periods of time and were not being collected. 